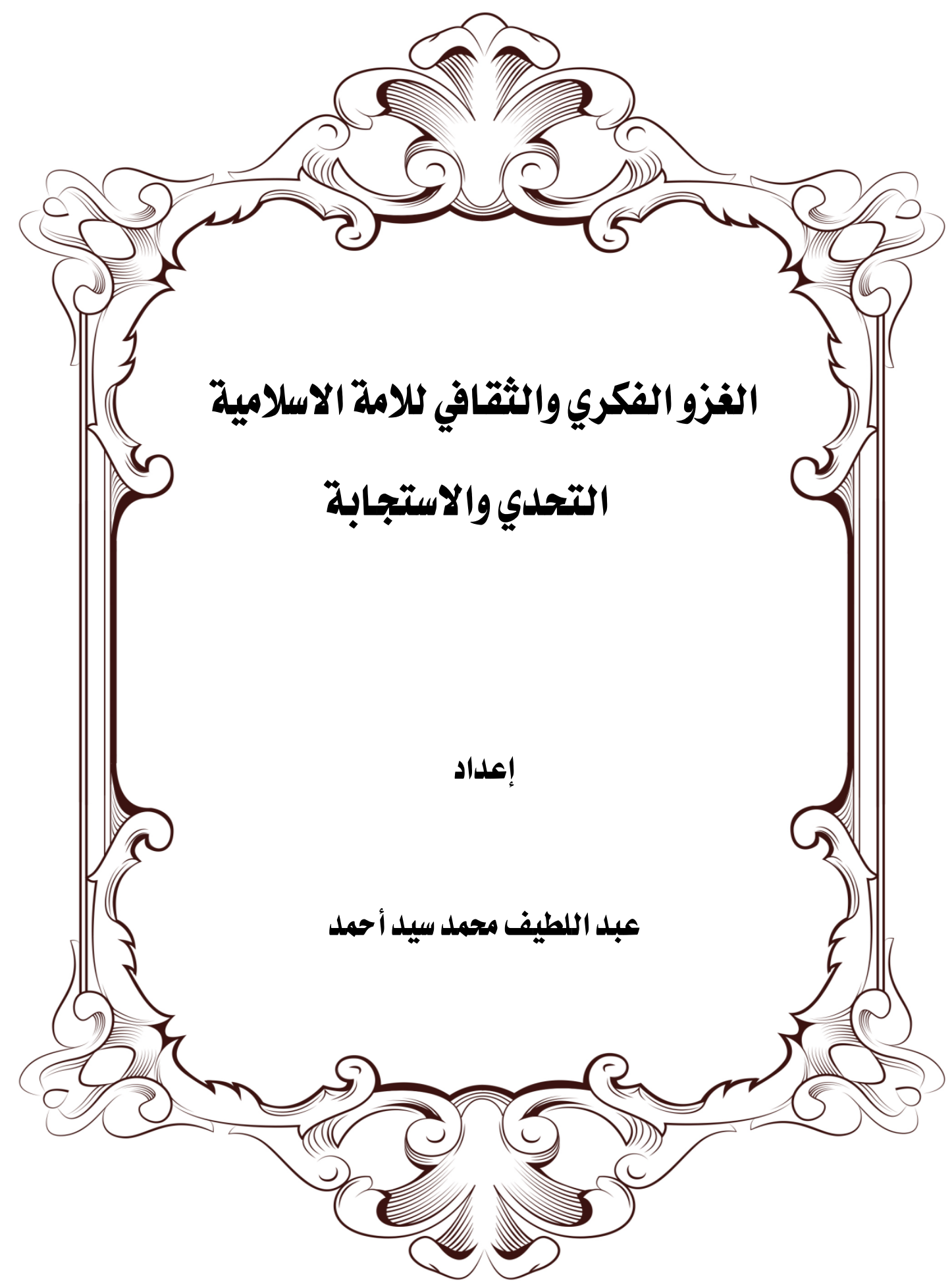




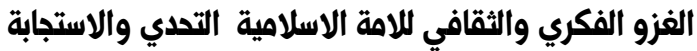

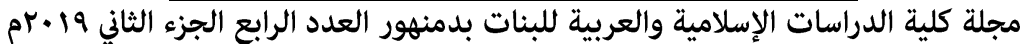




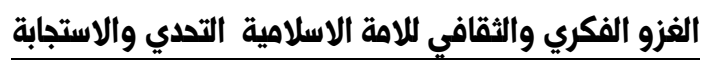

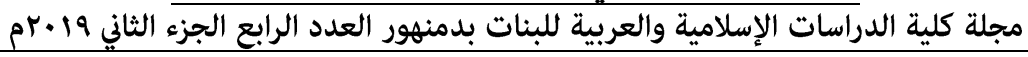

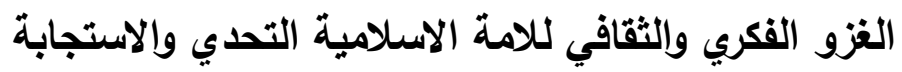

عبد اللطيف محمد سبد أحمد

\section{Dr.Abdul Latif@gmail.com}

ملخص بحث

كانت الحروب الصلبية علامة فارقة بين أوروبا والعالم الاسلامي ولم يقتصر

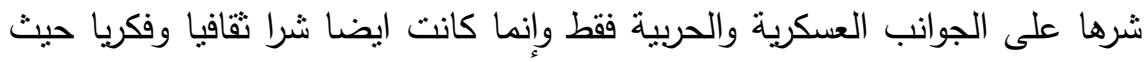
عملت الكنيسة على تسميم ذهن الانسان الاوربي بتصوير الاسلام والمسلمين بصورة

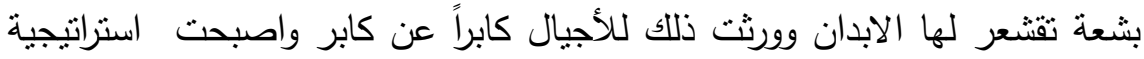

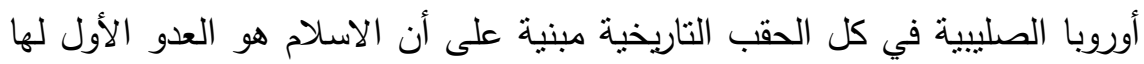

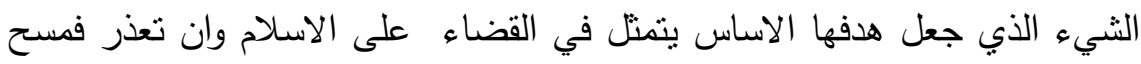

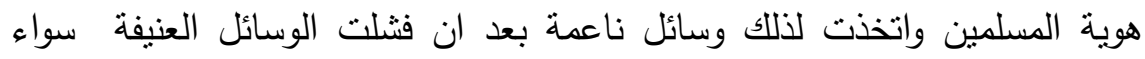

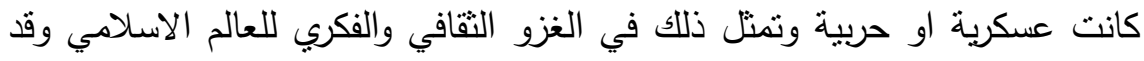

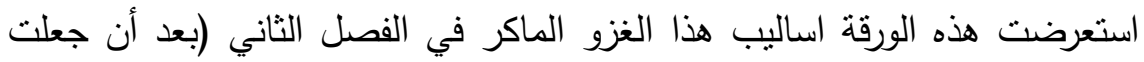

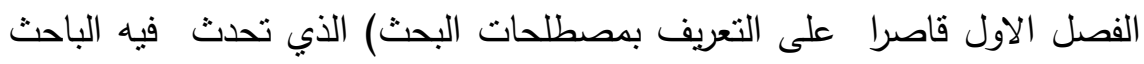

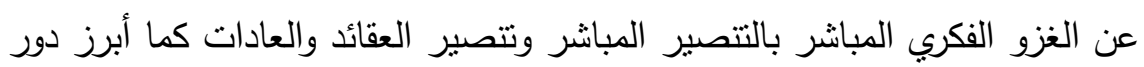

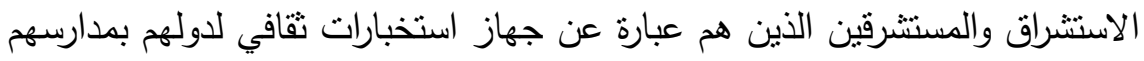

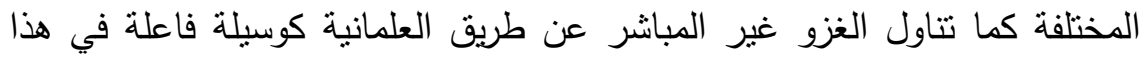

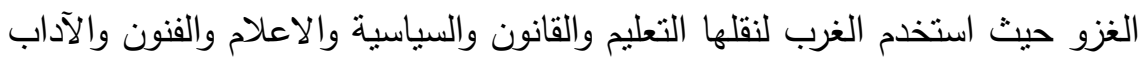

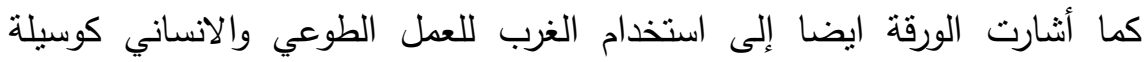

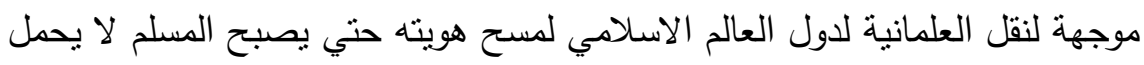

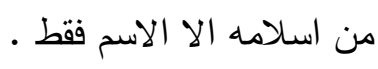
في الفصل الأخير تحدثت الورقة عن كيفية مواجه هذا الغزو الفكري الثقافي

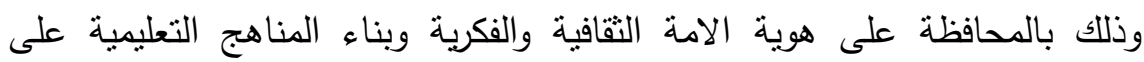

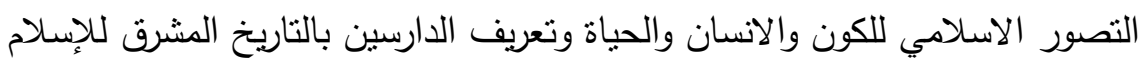

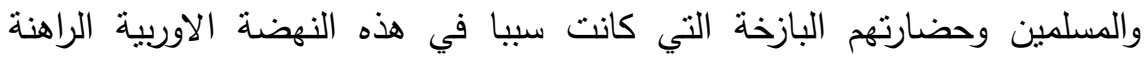
باعتراف علمائها ((والفضل ما شهدت به الأعداء)) بالإضافة للانها فئمام بتأصيل

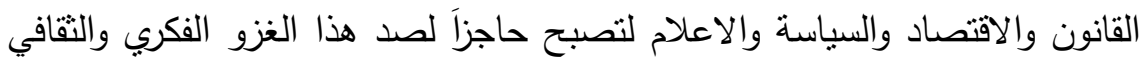
هذا من جانب ومن جانب أخر حتى لا يعيش المسلم في عزلة عالة عالئل يجري حوله في

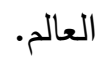
الكلمات الإفتتاحية: الغزو / الفكري / التقافي / الأمة الإسلامية / التحديات 


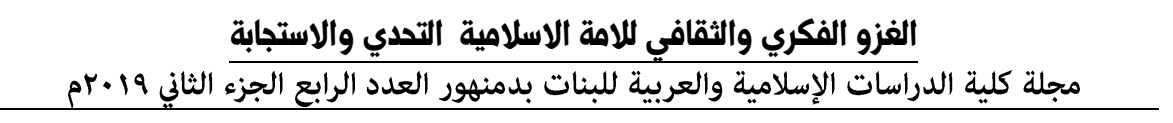

Abstract

The Crusades wars a were a milestone between Europe and Islamic world, and their role were not limited to the military and wars sides only, there were also a cultural and intellectual evil, where the Church worked to poison the mind of the European man Portraying Islam and Muslims in a hideous and chilling manner, and inherited this concept for generations to come. The Europe's Crusader strategy of all historical eras has been based on the fact that Islam is the first enemy which made its main goal is the elimination of Islam, if this is not possible, soft means have been taken such as the cultural and intellectual invasion of the Islamic world. This paper reviewed the methods of this insidious invasion in Chapter "2" (after the first chapter was limited to the definition of research terms)

The researcher spoke in the chapter "2" about the direct intellectual invasion by direct evangelization and the evangelization of beliefs and customs, he also highlighted the role of Orientalism and orientalists, which is a cultural intelligence for their countries in their various schools. He also dealt with indirect invasion through secularism as an effective means in this invasion, where the West used it to transfer education, law, politics, media, arts and literature. The paper also referred to the West's use of voluntary and humanitarian work as a means of transferring secularism to the countries of the Islamic world to delete its identity so that the Muslim does not carry from Islam any thing except its name.

In the last chapter, the paper talked about how to confront this cultural intellectual invasion by preserving the nation's cultural and intellectual identity and building educational curricula on the Islamic perception of the universe, man and life.

And educating the learners about the bright history of Islam and Muslims and their ancient civilization, which was the cause of this current European renaissance - recognized by their scientists. (and thanks to what witnessed by the enemies) in addition to interest in the consolidation of law, economy, politics and information to become a barrier to repel this cultural and intellectual invasion on one hand and on the other so that Muslim does not live in isolation from what is happening around the world.

\section{/ Challenges}

key words: Invasion / Ideological / Cultural / Islamic Nation 
بسم الله الرحمن الرحيم

جعلت أوربا الصليبية الصهيونية الاسلام عدوها اللدود منذ الحروب الصليبية التى منيت فيها بهزائم ساحقة جعلتها تحقد على الاسلام والمسلمين وازداد هذا الحقد ضراوة بعد أن سقطت القسطنطينية في ايدي المسلمين عام

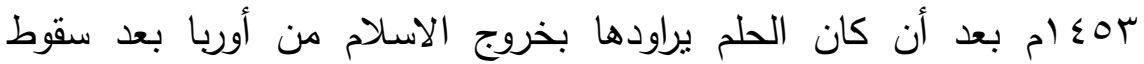
الأندلس ولم يرو هذا الحقد دماء المسلمين التى أريقيت هنالك. وحينما تمكنت

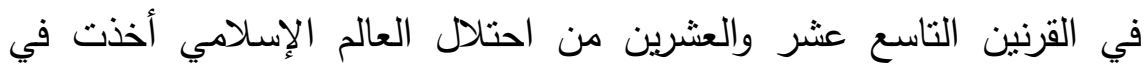
البحث عن الطريقة المثلي التي تقضي بها على جذوة الاسلام بعد أن لاحظت الاتبن

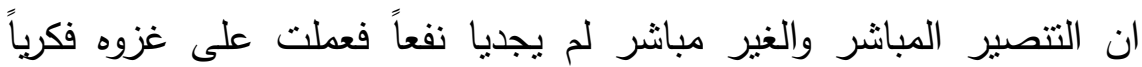

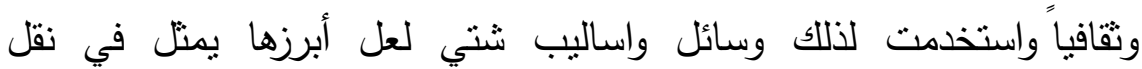
العلمانية لدول العالم الاسلامي فكان لابد من التتبيه لخطورة هذا الغزو وفضح اهدافه ووسائله حتي يتمكن المسلمين من مواجهته.

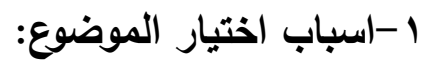

سبب اختيار هذا الموضوع يتمثل في العمل على كثف أهداف ووسائل واساليب الغزو الفكري والثقافي لأوربا الصليبية الصهيونية للامة الاسلامية فئية

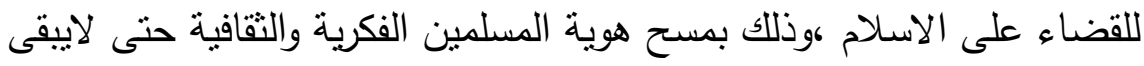

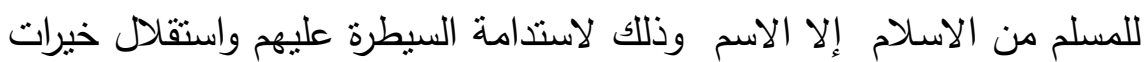

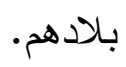

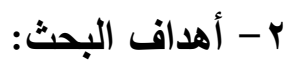

أ- تبصير المسلمين بخطورة الغزو الفكري والتقافي للأمة . البحت

ب- أن يعمل كل مسلم في مجاله على سد منافذ هذا الغزو. ج- أن تعمل الطليعة المسلمة على تأصيل العلوم السياسية والاقتصادية

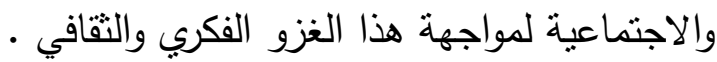


الغزو الفكري والثقافي للامة الاسلاهية التدلي والاستجابة

مجلة كلية الدراسات الإسلامية والعربية للبنات بدمنهور العدد الرابع الجزء الثاني 19 •rم

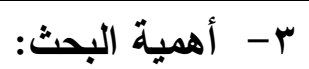

تتمثل أهمية الموضوع في حث الطليعة المسلمة على مواجهة هذا الغزو الفكري الثقافي وذلك بتعزيز مفهوم أن الاسلام هو عقيدة وشريعة

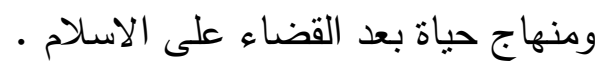

ع - منهج البحث: حسبة

يعتبر منهج الباحث في هذه الورقة منهجاً تاريخيا استقرائيا استتباطياً تحليلياً حاول أن يتتبع الغزو الفكري والثقافي وتطوره في حقب تاريخية مختلفة محلا ومعلاً لاسباب تغيير خططه واساليبه مرة تلو الاخري ثم استقرأ واستتبط ونطي

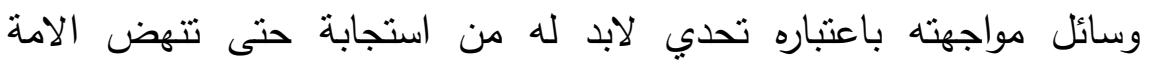
الاسلامية من كبوتها. ه- هيكل البحث -

يتكون البحث من مقدمة تشتمل على اسباب إختيار الموضوع، أهدافه، أهميته، منهجه وهيكله ثم تلي المقدمة ثلاثة فصول يحتوى كل فصل منها

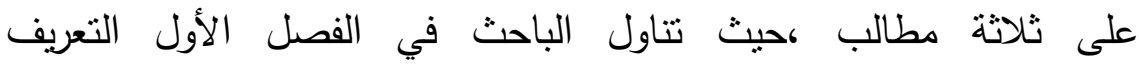
بمصطلحات البحث واحتوي الفصل الثاني على مهددات الأمن الفكري والتقافي لتاني للامة أما الفصل الثالث فقد رصد فيه الباحث وسائل واساليب مواجهة هذات البهات

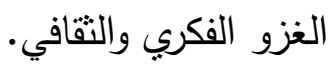




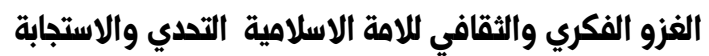

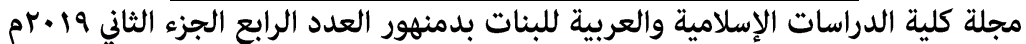

الفصل الأول

\section{تأصيل مفاهيم مصطلحات البحث}

يشتمل هذا الفصل على ثلاثة مطالب على النحو الآتي:

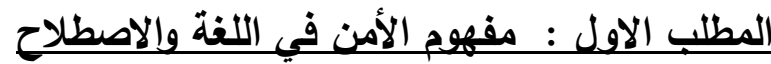

يعتبر الأمن من الحاجات البشرية الفطرية يجئ متلازماً مع حوجة

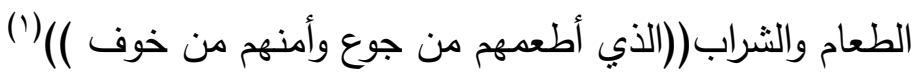

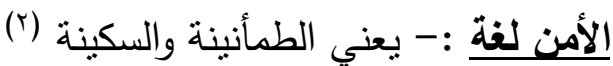

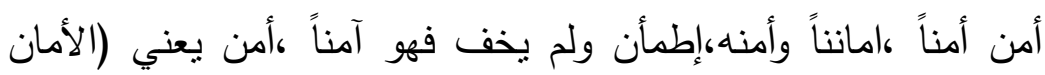

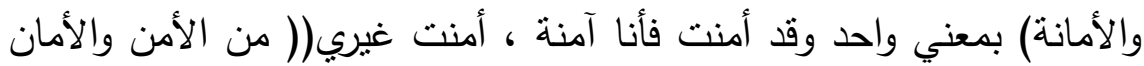

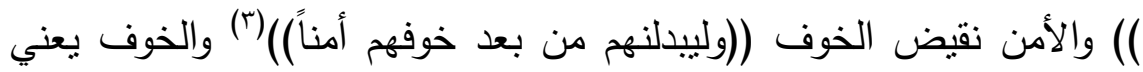
التهديد الثشامل سواء كان تهديداً عسكرياً أو سياسياً أو اقتصاديا أو اجتماعيا وبسبب عوامل داخلية أو خارجية وفي قوله تعالي (والتين والزينتون وطور سنين وهذا البلد الأمين )(؛) أي البلد الأمن الذي إطمأن فيه أهله. الأمن اصطلاحاً:- يعني الإجراءات التأمينية التي تتخذ لحفظ أسرار الدولة وتأمين أفرادها ومنشأتها الحيوية وقيمها ومصالحها القومية من الأفكار

$$
\text { والمهددات والأخطار الداخلية والخارجية. }
$$

ارتبط الأمن بنشأة الدولة القومية ولذلك أخذ في بدايته الطابع السياسي والعسكري وعمل على المحافظة على الدولة ككيان إقليمي في وجه الأخطار

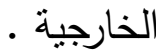

وفي سياق التطور التاريخي تطور مفهوم الأمن وذللك لبروز دور الايدولوجيا وتفاقم المشكلات الاقتصادية والاجتماعية في بعض المجتمعات لفروني الثئ الذي جعل أمن الدولة يأخذ أشكالاً متعددة ثقافية وفكرية واجتماعية لإنية

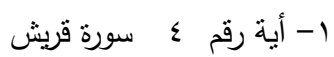

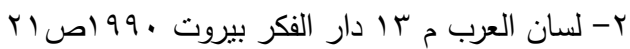

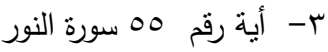

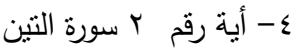




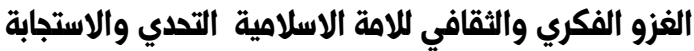

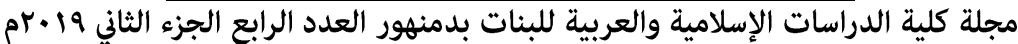

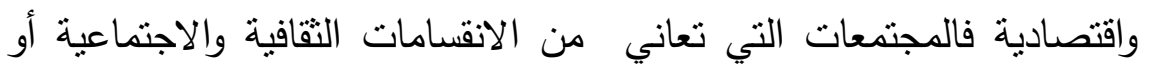
التخلف الاقتصادي تصبح أكثر عرضه لتهديد أمنها من قبل القوبالخارجية بل قد يتهدد ذاتياً من جراء تفاقم الانقسامات الثقافية والاجتماعية دونما حاجة

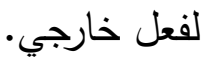

من هنا أخذ مفهوم الأمن هذه الابعاد ولم يعد قاصرا على البعد الاستراتجي العسكري وحده وهو ما يعرف بالمفهوم الثامل للأمن وذلك يعني أن الأمن ما عاد بعني قوة الدولة العسكرية فقط بل بعني قدرة الدولة كمفهوم أثمل من القوة لأنها تعتبر احد عناصر القدرة التي هي عبارة عن نسبج متشابلك تتداخل فيه العناصر السياسية، الاقتصادية ، الاجتماعية ، الثقافية ، التكنلوجية والإعلام وهذا ما يعرف أيضا بالأمن غير التقليدي.

\section{تأصيل مفهوم الأمن الفكري- :}

اهتم الصحابة رضوان الله عنهم أول ما اهتموا بالأمن الفكري فكانت دعوة عمر ابن الخطاب للخليفة أبو بكر الصديق بجمع /القران خوفاً من التحريف والتصحيف رغماً من أن الله تكفل بحفظه حين قال) ؛ إنا نحن نزلنا الذكر و إنا له لحافظون)(') فهو لا شك المصدر الفكري الأول للمسلمين وهم بهذا فقد عملوا على نقل القرآن نقل كافه عن كافة((منهج التواتر)) وليس نقل افراد كما هو الحال في نقل التوراة والإنجيل مما عرضهما للتحريف والتصحيف. ثم جاءت الخطوة الثانية بتأمين المصدر الفكري الثاني للمسلمين وهو السنة المطهرة فقد ابتكر الصحابة من الوسائل التي تأمنها وتحميها من التصحيف وتعمل على تبيين الحديث الصحيح من الموضوع من الضعيف.....الخ. فنشأت علوم الرواية والدراية أي السند والمنن ثم كان علم الجرح والتعديل(علم الرجال) وأغلقوا بذلك الباب على الوضاعين والمنافقين كعبداله بن سبأ اليهودي(r) وغيره ثم عملوا بذات النهج على حفظ التاريخ

$$
1
$$

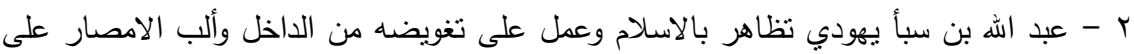
سيدنا عثمان بن عفان مما أدى لمقتله وظهور الفتنة الكبرى بين المسلمين. 


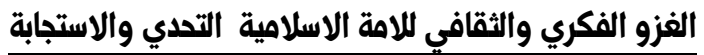

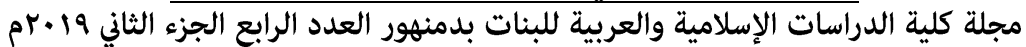

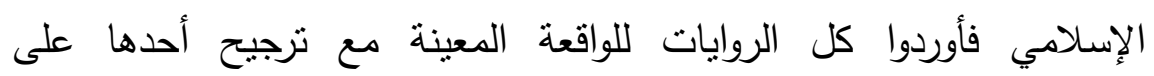
الأخريات.

اللغة العربية:-

لما كانت اللغة العربية هي الوعاء الذي يحمل الوحي (القرآن والسنة)

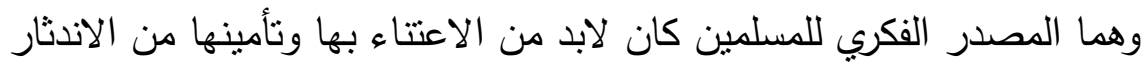

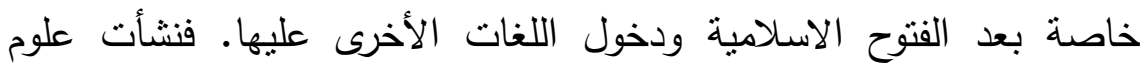
العربية كالنحو والصرف والبلاغة...الخ. والتي عملت أيضاُ على تسهيل

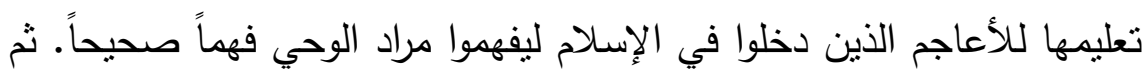

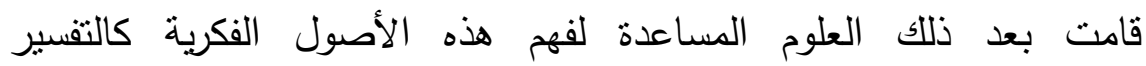

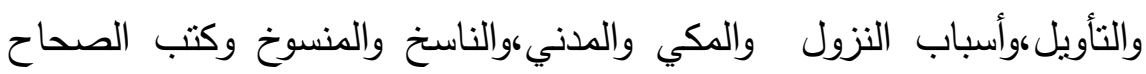
والمساند والمجامع والمستدركات الخ. الدولة الفارسبة:-

دخل الإسلام الى بلاد فارس بعد سقوط الامبراطورية الفارسية الثيء

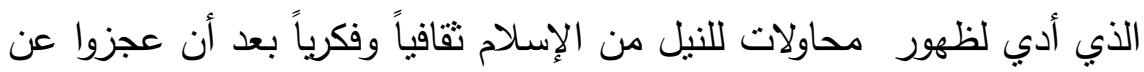

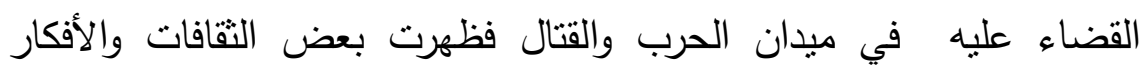
المنحرفة والثاذة وعملوا على الصاقها بالاسلام كالمجسمة والرافضة والقرامطة

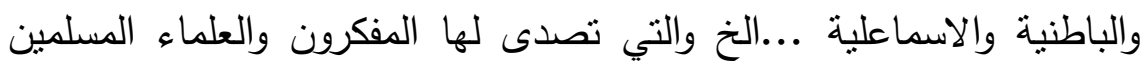
بالتفنيد والدحض على مدار التاريخ فأمنوا بذلك عقول المسلمين وأفكارهم وهو ما يحتاج له المسلمون في كل زمان ومكان ومن هنا تجئ أهمية الأمن الفكري والنقافي.

المطلب الثاني :- مفهوم الفكر في اللغة والاصطلاح

الفكر لغة :- الفي

هو أعمال الخاطر في الثـئ يقول الجوهري(') التفكير في الثئ يعني التأمل، الاسم يعني الفكر والفكرة والمصدر الفكر

$$
\text { 1 - ابن منظور لسان العرب م( دار الفكر بيروت •99 اص V) }
$$




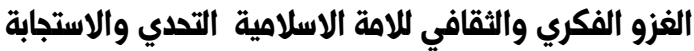

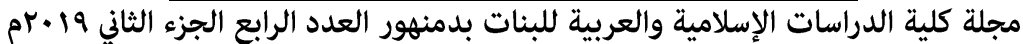

الفكر في الاصطلاح:- يعني أعمال الذهن في آيات الله المسطورة

والمنظورة وذلك بالتثبر في البيئة المحيطة بالإنسان لمعرفة الوسائل والطرق التي يمكن بها تسخيرها لخدمته وترقية أساليب معاشه مستخدماً الملاحظة

$$
\text { والتجربة والاستقراء والاستتباط العقلي. }
$$

يعتبر التفكير السمة الأساسية للإنسان والتي يختلف بها عن كل الكائنات ولذلك حينما أرادوا أن يعرفوا الإنسان، قيل ((الإنسان حيوان مفكر)) وأن كان من الصعب تحديد نقطة بداية التفكير الإنساني ولعلها ترجع إلي قصة هابيل وقابيل (( ياويلتي أعجزت أن أكون منل هذا الغراب فأواري سوأة أخي )(') وعلى مستوى الأمم والثعوب ربما يرجع التفكير لحضارات الثرق في وادي الفرات والنيل والهند والصين ثم الحضارة اليونانية حيث افرز التفكير حصيلة ضخمة دن المعارف ساعدت الإنسان في هذه الحضارات على تحقيق انجازات مادية كبرى بالإضافة للأديان والفلسفات ،وان ربط التفكير بقدماء اليونان خاصة برجع في اعتقادي لأنهم يمنلكون حافز أخر يضاف

$$
\text { إلي حافز الانجاز العملي هو الرغبة في الإقناع • }
$$

عم الركود في التفكير العصور الوسطى الأوربية (س-ع ا) من القرن الثالث حتى الرابع عثر حيث ساد فيها أن العلم بلغ قمته العليا عند ارسطو و ما قاله هو الكلمة الأخيرة في أي ميدان من ميادين العلم وفي مقابل ذلك في العالم الإسلامي كانت هناك حضارة فتية تتسم بالايجابية والتوسع والانفتاح على العالم فقد عرف المفكرون المسلمون علوم اليونان ،الفرس، الهند وأعاد التفكير الإسلامي النظر في هذا التراث العلمي اليوناني النظري حيث كانت ممارسة العلماء المسلمين تسير في اتجاه العلم التجريبي واستخدام البحث العلمي من أجل فهم قوانين الطبيعة المحيطة به وقد أخذوا ذلك من إثارات القرآن المتكررة للتدبر في أيات الكون والأنفس (( سنريهم آياتنا في الآفاق وفي أنفسهم حتى يتبين لهم أنه الحق)(؟)((إن في خلق السموات والارض واختلاف والات 


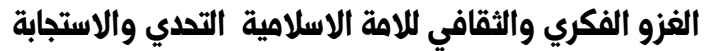

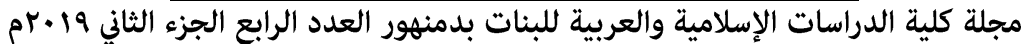

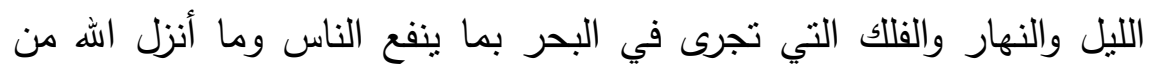

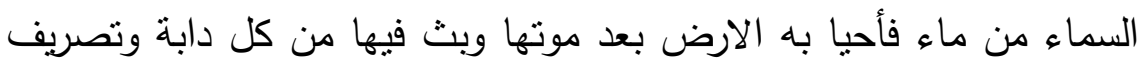

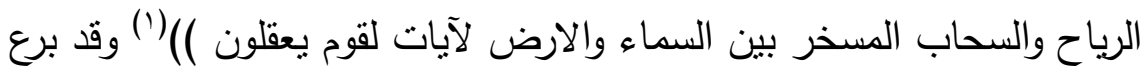

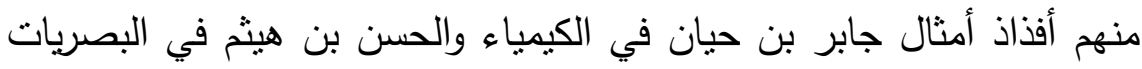

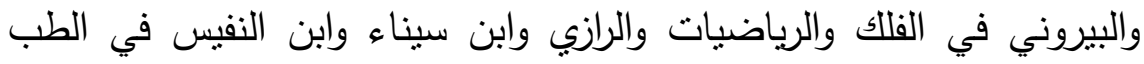
وغيرهم وقد كان هدفهم من ذللك استخدام هذا التفكير من اجل كثف أسرار العالم الطبيعي وتمكين الإنسان من السيطرة عليه ويعتبر هذا المنهج الذي

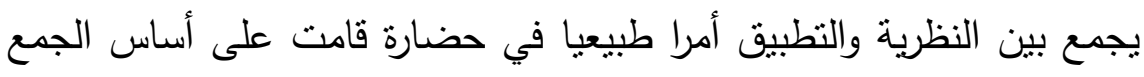

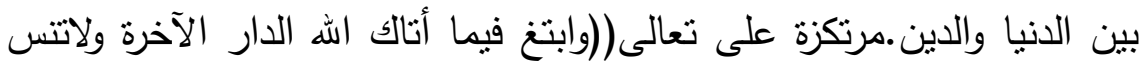

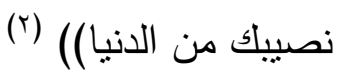

هكذا تعلم المسلمون من الإسلام أمرين في أن واحد البحث والتدبر في

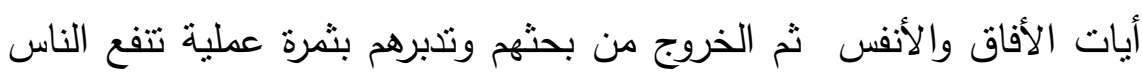

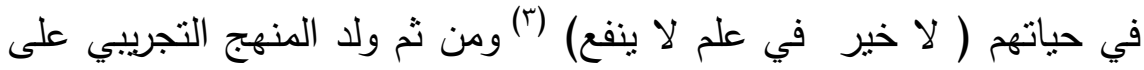
أيديهم يقول بريفولت (أما ما ندعوه العلم فقد ظهر في أوربا نتيجة لروح من البحث جديدة ولطرق من الاستقصاء مستحدثة من طرق التجربة والملاحظة

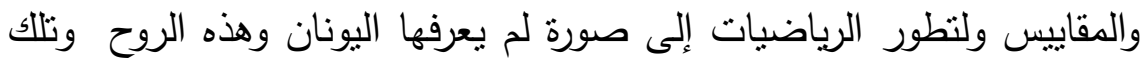

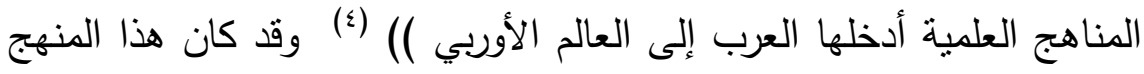

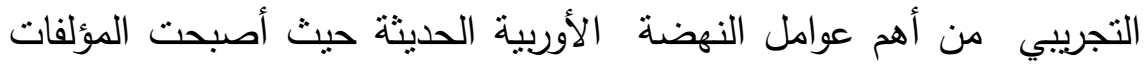
العربية منذ القرن الثاني عشر تترجم إلى اللغة اللاتينية وأظهرت الفروق بين التفكير الفلسفي الموروث من قدماء اليونان والتفكير العلمي الموروث من لن

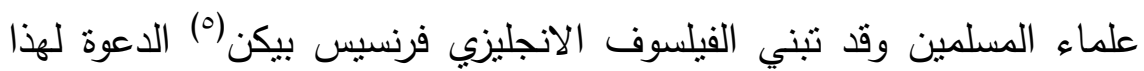

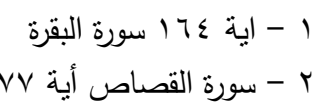

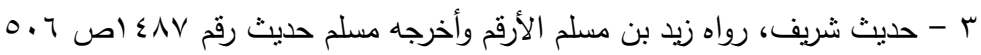

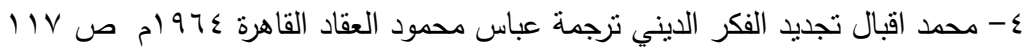
ه - فيلسوف انجليزي يعتبر أحد دعاة الفلسفة المادية التي تعتبر الحواس الخمسة وسيلة المعرفة 


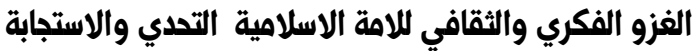

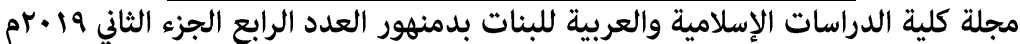

المنهج الجديد ليستقل بعدها العلم عن الفلسفة التي تقوم على التأمل أما العلم فيعتمد على الملاحظة والتجربة واستقراء الظواهر بالإضافة للاستتباط العقلي وتعليل الظواهر ومعرفة أسبابها كيقول بريفولت أيضا ((أن روجر بيكون(') درس العربية والعلم العربي في مدرسة اكسفورد على خلفاء معلميه العرب في الاندلس وليس له ولا لسميه فرنسيس بيكون الذي جاء بعده الحق في أن ينسب اليهما الفضل في ابتكار المنهج التجريبي فلم يكن روجر بيكون الا رسولا من رسل العلم والمنهج الإسلامي إلي أوربا المسيحية وهو لم يمل قط من التصريح بأن تعلم معاصربه للغة العربية وعلوم العرب هو الطريق الوحيد للمعرفة الحقة )(؟) قاد هذا المنهج التجريبي أوربا لاكتشافات غيرت الكثير من المفاهيم التي كانت سائدة في القرون الوسطى والتي كانت تعتبرها الكنيسة معارف مقدسة مما دفعها لمحاربة العلماء والمفكرين وحرقهم وتعذبيهم وكانت ردت فعلهم هى الدعوة للكفر بالكنيسة وإلها والدعوة لعبادة الطبيعة وقيام نظريات فلسفية مادية تعتمد على التأمل والفكر الحر كالثيوعية والوجودية وغيرها ترفض الدين جملة وتفصيلا وأخرى كالعلمانية والقومية وغيرها تدعو إلى فصل الدين عن الدولة. المطلب الثالث :مفهوم الثقافة لغة واصطلاحاً:

الثقافة لغة :-

هي من ثقف الثيء بعنى شحذه وهذبه وتعنى أيضاً الانقداح والتولد ثم استعملت مجازاً بمعنى تقويم العقل وتهذيبه كما استخدمت بمعنى الفطانة أما اصطلاحًا فتعنى طريقة التفكير والسلوك وأسلوب الحياة من المعاش والملبس والمأكل والمشرب والمعتقد والأخلاق والقيم والآداب والفنون والعادات والتقالبد

والإرث التاريخي للأمة. نلاحظ أن مصطلح الثقافة يزاوج بين الكسب العلمي والمعرفي والاستيعاب الفني والأدبي والنمط السلوكي في الحياة وهذا بعنى أن

$$
\begin{aligned}
& \text { 1- مفكر انجليزي يعتبر أحد رواد النهضة الاوربية }
\end{aligned}
$$

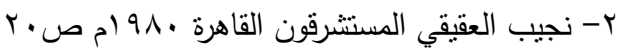




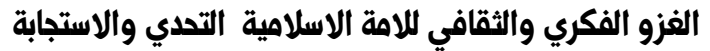

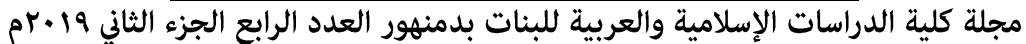

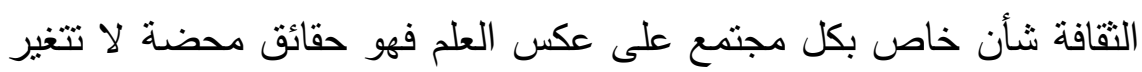

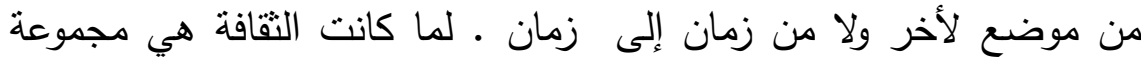

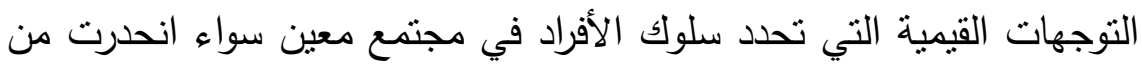

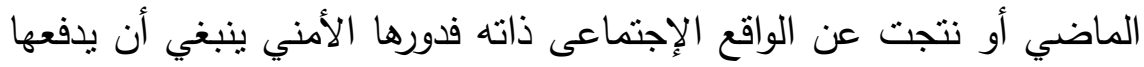

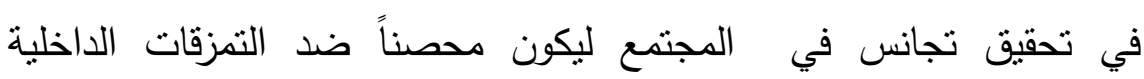

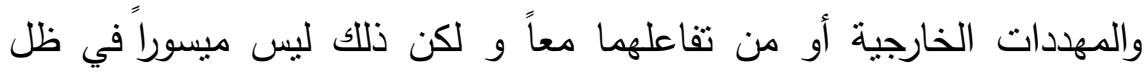
سيطرة مفاهيم الثقافة الغربية وقيمها تحت غطاء الحريات المختلفة الثخصية والسياسية والاقتصادية والدعوة للثفافية وحقوق الإنسان وتأثثر ثقافة الانترنت والفضاءات المفتوحة التي يركز الغرب على بثها في دول العالم الإسلامي ولإني لمحو هويته النقافية والفكرية واستلابه ثقافيا وفكريا مستقلا تبعية بعض أفراد بهاد

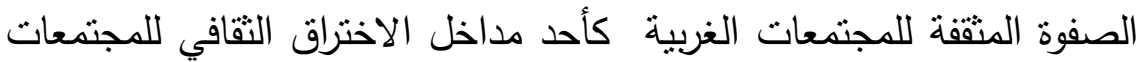

$$
\text { المسلمة في بلادها. }
$$

\section{علاقة الثقافة بالحضارة والمدنية- بده:}

الحضارة تعنى سكون الحضر • والحاضر هو المقيم في القرى والمدن

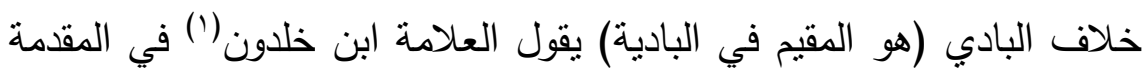

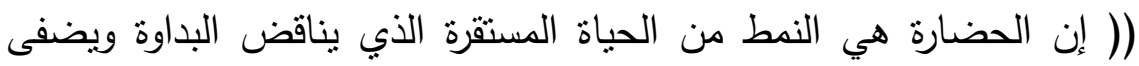

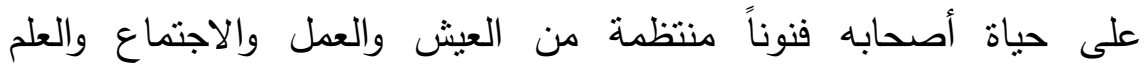
والصناعة)) والمفهوم العام للحضارة يشمل جميع أوجه الحياة المادية والمعنوية. والنقافة إذن تعنى بالجانب الفكري والعقدي والخلقي في حياة الأمة أما المدنية فهي نسبة إلى المدينة فتعنى بالجانب المادي المتمنل في التفنن في أساليب العيش والمسكن والملبس والمركب وغير ذللك وبهذا المفهوم تكون الحضارة هي الحصيلة الثاملة للمدنية والثقافة ولا يمكن أن توجد وضلين ولثارة

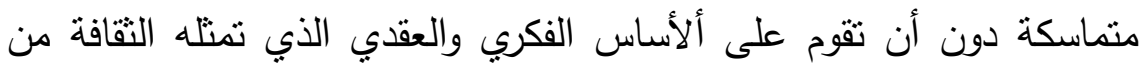
جانب وعلى التقدم المادي الذي تمثله المدنية من جانب أخر .

1 هو عبد الرحمن ابن خلدون المفكر المغربي المشهور - صاحب المقدمة المشهورة مقدمة ابن

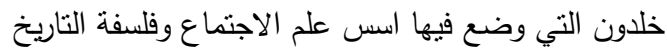




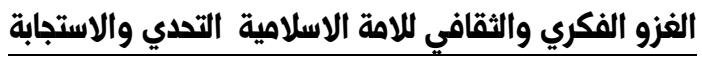

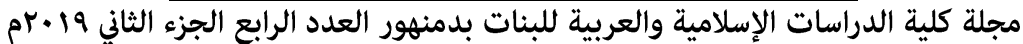

| (الفصل الثاني

مهددات الأمن الفكري والثقافي للامة.

يحتوي هذا الفصل على ثلاثة مطالب هي-:

المطلب الأول:- الغزو الفكري المباشر-

باءت محاولات الغرب المتكررة لهزيمة المسلمين والقضاء على الاسلام

في الحروب الصليبية وبالاحتلال المباشر والاستعمار في القرن التاسع عشر بالفثل وتكبدوا خسائر فادحة في الأرواح والأموال الثيء الذى جعله يفكر بعدها في وسائل أخرى غير المواجهة العسكرية العنيفة لغزو العالم الإسلامي وهزيمته فعمل على غزوه ثقافياً وفكرياً عبر محورين هما التتصير والاستشراق. التتصير-: هو عملية تحويل الافراد أو الثعوب الى الديانة المسيحية

بالفرض القسري او التحول الثقافي والحضاري بدلاً عن ثقافتهم الاصلية. انطلق المنصرون مع الطلائع الأولى للاستعمار الصليبي لدول العالم الإسلامي لتصير عوام المسلمين مستلغين جهل بعضهم بحقيقة الاسـام للتقرير بهم مستخدمين لغة الثتائم والتجريح للإسلام والمسلمين ولما تبين لهم استحالة ذلك عدلوا عن التصير المباشر لتصير أفكار المسلمين وعاداتهم وتقاليدهم ونظرتهم للحياة يقول لورد كرومر (1) حاكم مصر الانجليزي في ذلك ((إن مهمة الرجل الأبيض الذي وضعته العناية الإلهية على رأس هذه البلاد أن بجعل النصرانية هي قاعدة التعامل مع المحافظة التامة على المظاهر الخاوية للدين الإسلامي كعطلة الجمعة والعيدين وما إلى ذلك منعاً من إثارة

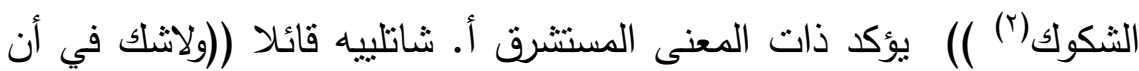
الإرساليات التبشيرية من بروتستانتية وكاثولكية تعجز عن أن تزحزح العقيدة الإسلامية من نفوس منتحليها ولا يتم ذلك إلا ببث الأفكار التي تتسرب مع اللغات الأوربية فبنشرها (الانجليزية والألمانية ، الهولندية ، الفرنسية ))يحتلك الإسلام بصحف أوربا وتتمهد السبيل لتقدم إسلامي مادي وتقضي ارساليات

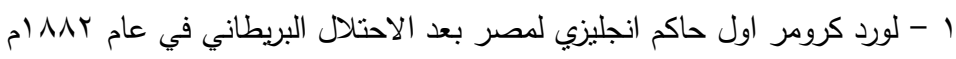

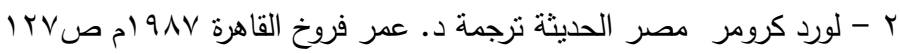




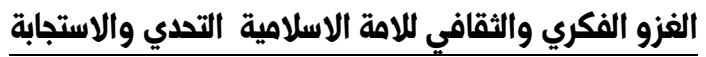

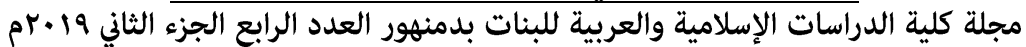

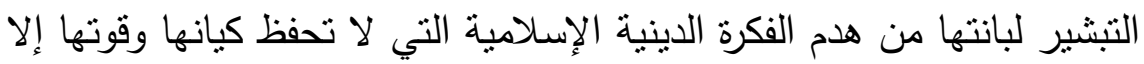

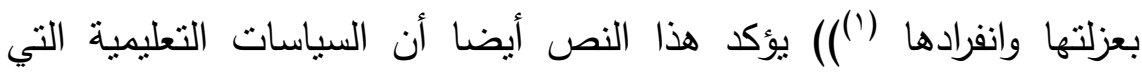
وضعها المستعمر الهدف الأساسي منها هو نقل العلمانية لدول العالم الإسلامي إذ في هذا النص يثير المستشرق لأهمية تعليم اللغات الغربية ويشير لدورها الفاعل في التتصير الفكري للمسلمين.

يتضح بهذا أن التصير هو عملية سياسية صليبية وليس مجرد محاولة لنشر الديانة المسيحية وهو أذن من أهم وسائل الغزو الفكري التى استخدمت لهني

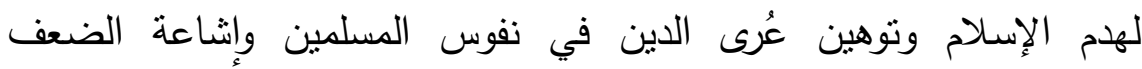
والانحلال فيهم ليستولى الغرب عليهح وذللك بالربط بين واقع المسلمين

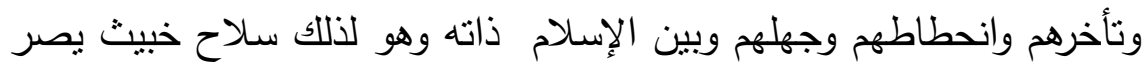
الغرب على استخدامه لصرف المسلمين عن التمسك بالإسلام، يقول شاتليه (ولا ينبغي لنا أن نتوقع من جمهور العالم الاسلامي ،أن يتخذ له أوضاعاً

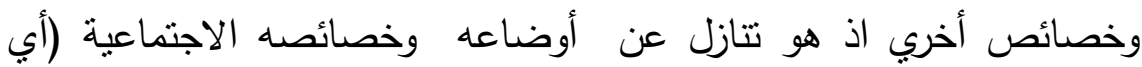

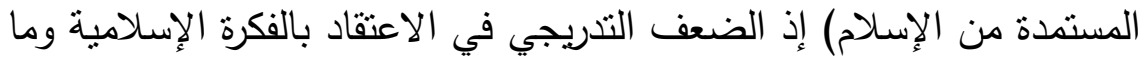

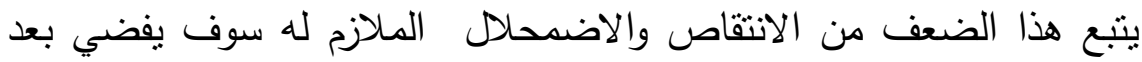

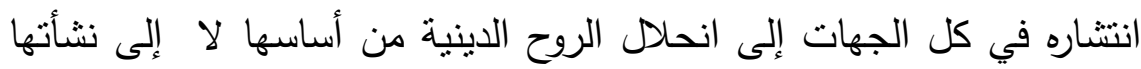

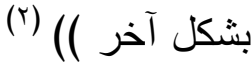

يعنى ذللك أن يكون الإسلام هو مجرد أن يحمل الإنسان اسماً إسلامياً

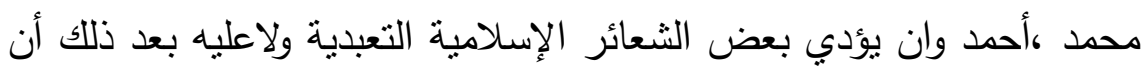

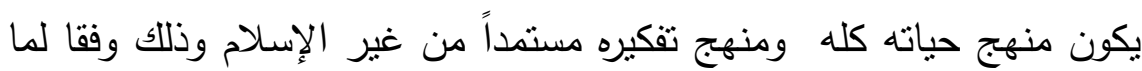

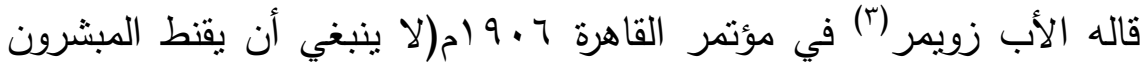

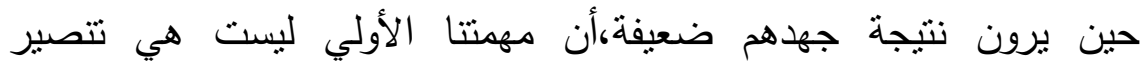

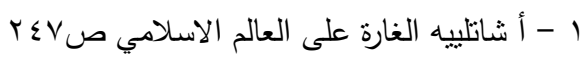

$$
\begin{aligned}
& \text { r }
\end{aligned}
$$

r - قسيس ومبشر انجليزي نذر نفسه للتنصير في افريقيا وآسيا 


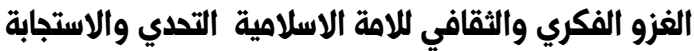

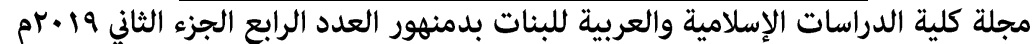

المسلمين وانما هي صرف المسلمين عن التمسك بالإسلام وفي هذا نجحناً

نجاحاً باهراً بكل نأكيد (أنمين (1)

إن جهود التتصير وهن بعدها جهود الإستشراق وهي مجرد امتذاد لها

استطاعت ان تفعل كثيراً في الغزو الفكري بصرف المسلمين عن التمسك

بدينهم وكانت بذاك أكبر سند للستعمار الصليبي الصهيوني الذي يرصد الإمكانات المادية والعلمية والمالية الضخمة للتصير والاستشراق للقضاء على

\section{الاستشراق:}

يعني دراسة الثرق لغاته وأديانه وتاريخه وجغرافيته الطبيعية والبشربة .

إن الاهتمام بدراسة اللغة العربية والعلوم الاسلامبة التي هي موضوع الاستشراق قديم في أوربا برجع إلى العصور الوسطى واتخذ عدة اطوار مربوطة في كل طور بدوافع دينية وسياسية واقتصادية لأوربا يمكن حصرها في الآتي:-

الطور الأول :- في القرون الوسطي اتجهت أوربا للاندلس وشمال أفريقيا ليتعلم ابناؤها العربية والعلوم الاسلامية من طب وهندسة وفلك وفيزياء ........ يقول نجيب العقيقي (وبدأ الاستشراق اكثز ما يكون نتظيماً وانتشاراً واستمراراً بالفاتيكان باباوات واساقفه ورهباناً)(؟) حيث كان الاستشراق في هذا الطور يهدف للتزود بالمعارف والعلوم والتي لم تكن مناحة يومئذ الا عند المسلمين .ويقول ايضاً)(وكان رجال الدين ومركزهم الفاتكان يومئذ يؤلفون الطبقة المتعلمة في أوربا ولاسبيل إلي ارساء نهضتها الا على اساس من التراث الانساني الذي تمثله الثقافة العربية فتعلموا العربية ثم البونانية ثم اللغات

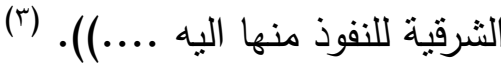

$$
\begin{aligned}
& \text { ا نجيب العقيقي المسنترقون القاهرة } 910 \text { اصل • }
\end{aligned}
$$

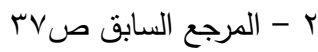

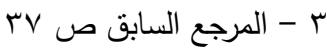




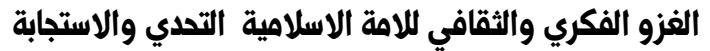

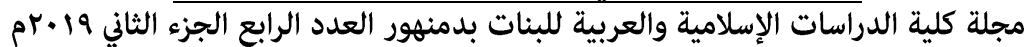

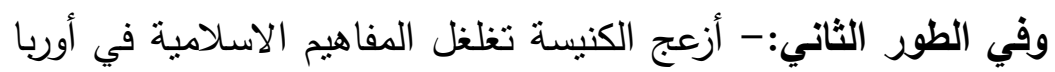

فقامت تنافح عن نفسها بمحاكم التفتيش وتجنيد رجالها لنشويه صورة الاسلام في نفوس الناس لتنفيرهم منه وابعادهم عنههولم يكن موققها من العلماء الذين

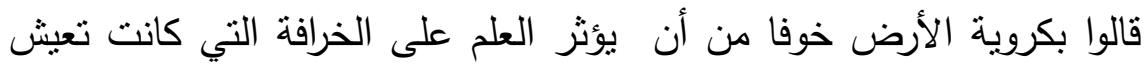

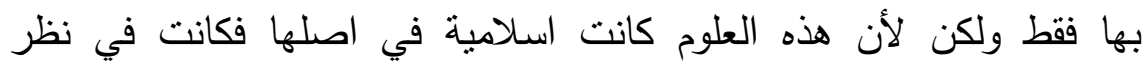
الكنيسة غزواً فكريا اسلامياً يجب التصدي له بكل قوة حتي لايمتد أثره في

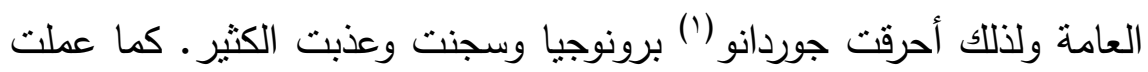
على تتفير الأوربيين من الإسلام وتصويره بصورة منكرة وكلفت كتابها وفنانيها بأن يقوموا بهذا التثوية المتعد وجيشت الجيوش لحرب المسلمين ونين بحجة استرداد بيت المقدس متخذة الصليب شعاراً لها فيما عرف بالحروب الصلبية

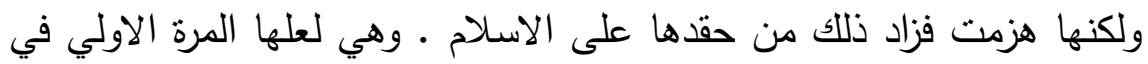

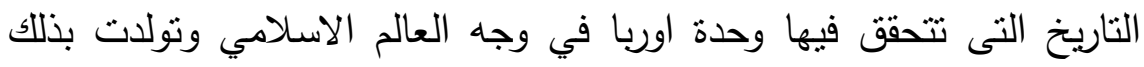

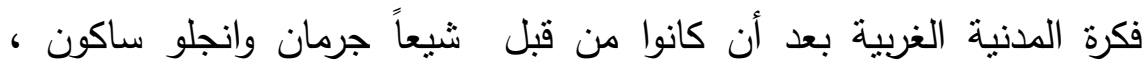

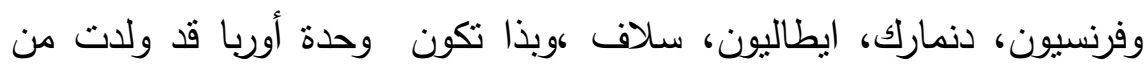

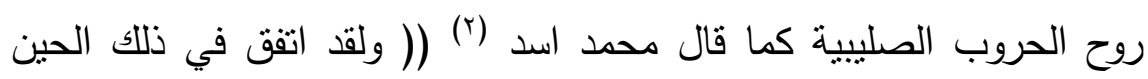
وللمرة الأولى في التاريخ أن أوربا أدركت في نفسها نفال وحدة ولكنها وحدة في

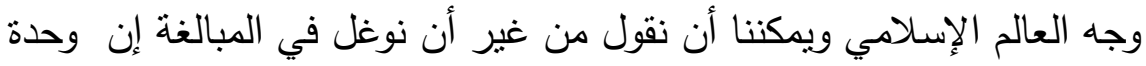

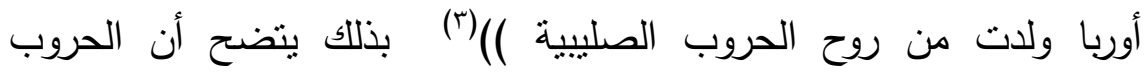

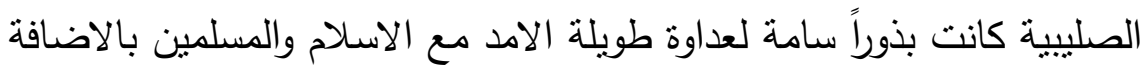
للثر التقافي الذي نشأ بتسميم العقل الأوربي بتشويه الكنيسة لتعاليم الاسلام

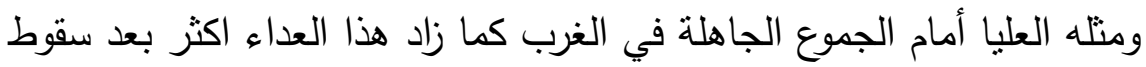

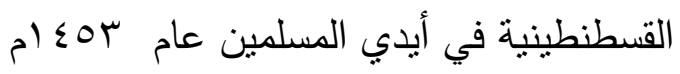

1 Y- محمد اسد مستشرق نمساوي كان اسمه ليبولد فانيس اسلم وسمى نفسه محمد اسد الإضد

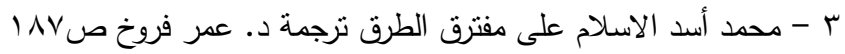




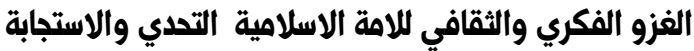

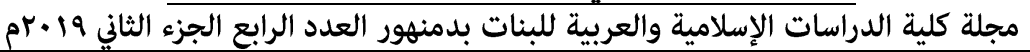

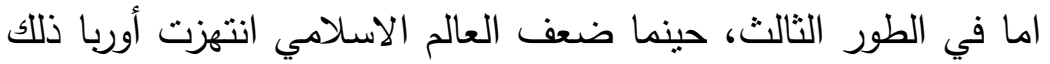
فأخذت في احتلال دول العالم الاسلامي بحثاً عن المواد الخام والاسواق التان

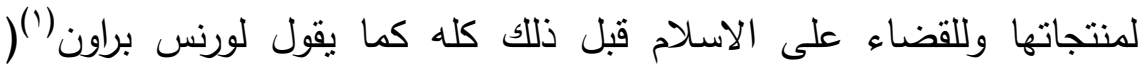
الخطر الحقيقي كامن في نظام الاسلام وحيويته انه الجدارالوحيد في وجهاء

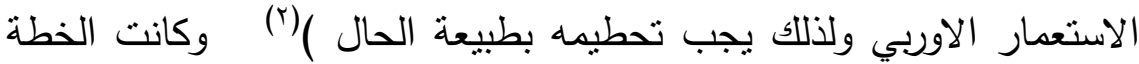

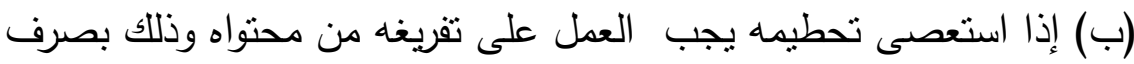
المسلمين عن التمسك بالاسلام وفتتنهم عن مصدر قوتهم الحقيقي وتوهين عرى الدين في النفوس ولاييقى منه إلا صلة العبد بربه في صورة شعائر دينية

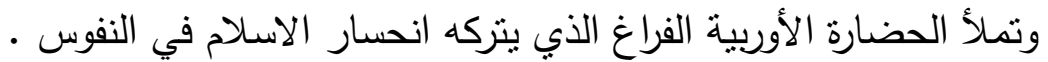

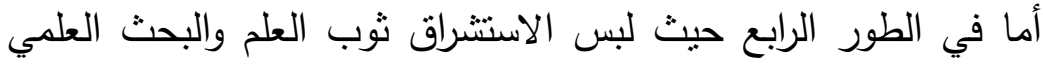

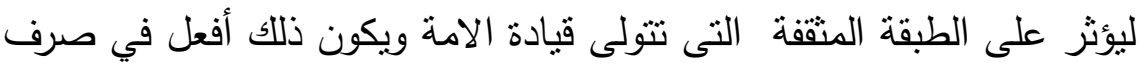

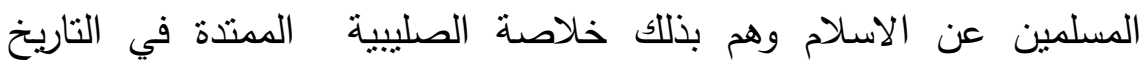

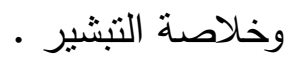

يقول محمد أسد (( أما تحامل المسنترقون على الاسلام فغريزة موروثة وخاصة طبيعية تقوم على الموروثات التي خلفتها الحروب الصلبية بكل ما لها

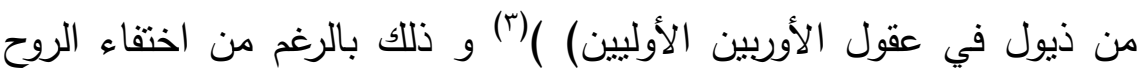
الديني الذي كان سبب العداء مع العالم الاسلامي بسبب المناخ المادي الذي لإني يعيشه الغرب إلا أن النفور القديم قد بقي في العقل الباطن للأوربين ومازالت تغمر حضارتهم روح الحروب الصليبية .

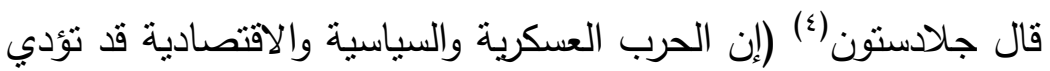
إلى اخضاع العالم الإسلامي ولكنها لن تؤدي الى صرفه عن الاسلام وهو

1 - لورانس براون مستشرق انجليزي

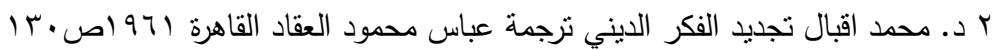

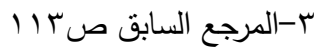
ع -جلادستون رئيسوزراء بريطاني سابق ويعتبر أحد مهندي الاستعمار البريطاني صليبي حاقد علي الاسلام والمسلمين 


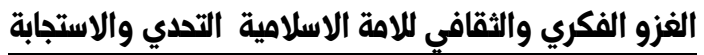

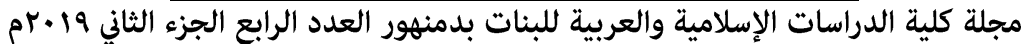

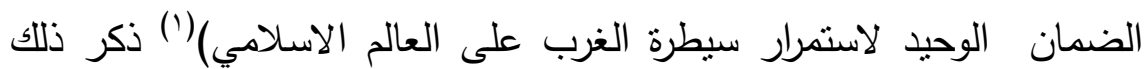

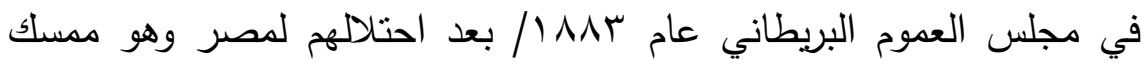
للمصحف في يده( طالما كان المصريون متمسكين بهذا الكتاب فلن يقيم لنا قرار في تلك البلاد)،ولذلك كان التتصير والاستشراق الذي هو امتداد للأول دور كبير في صرف المسلمين عن دينهم وبذلك فهما سنداً للاستعمار الصليبي الصهيوني. وقد أخذ الاستشراق الحديث بعمل على دئ الآتي:1- رصد كل نشاط اسلامي فكري او حركي في دول العالم الاسلامي وابلاغ الاغل

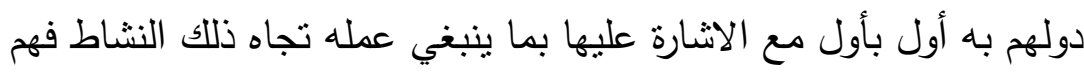
بهذا جهاز مخابرات ثقافي. r- التشويش على المسلمين وفنتتهم عن دينهم وتتشتيت جهودهم وافكارهم عن إقامة حركة بانية هادفة لتحقيق الاسلام في الارض في أب بلد من بلد بلاد

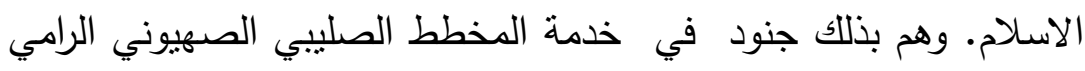

$$
\begin{aligned}
& \text { الى القضاء على الاسلام. } \\
& \text { المستشرقون :- }
\end{aligned}
$$

هم ورثة المنصرين وان كان الأقدمون من المستشرقين لا يختلفون كثيراً

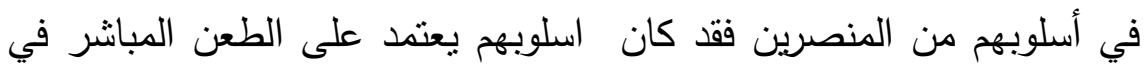
الاسلام والتجريح والتشويه والتتفير والدعوة السافرة إلي الخروج من الاسلام أما فيان المحدثون منهم فقد أخذوا السمت العلمي الموضوعي والمنهجي وذلك لأن الصليبية خشيث أن يقود التتصير الصريح لدفع المسلمين للتمسك بدينهم أكثر

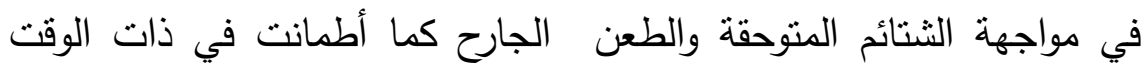

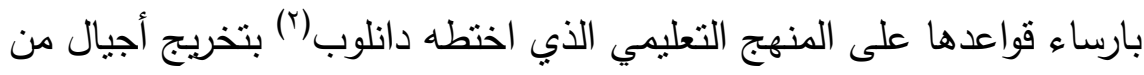

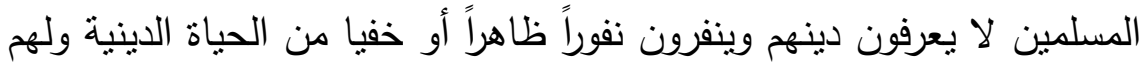

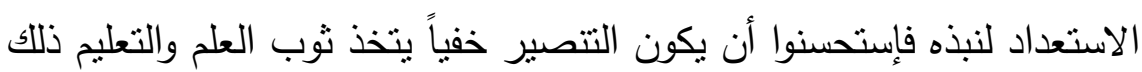

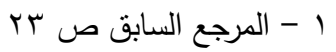

r - مستر دانلوب قسيس انجليزي خريج مدرسة اللاهوت لندن انتدبه لورد كرومر لوضع السياسة

$$
\text { التعليمية في مصر دانل مصنر }
$$




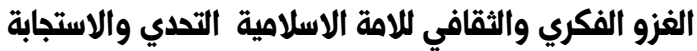

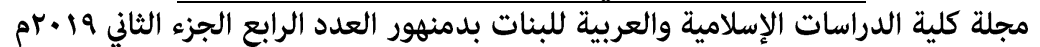

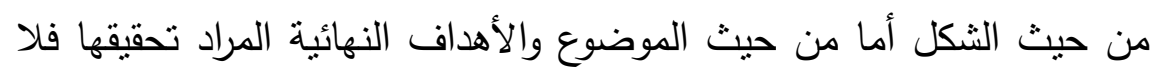

خلاف بين المنصرين والمستشرقين القدامى والجدد.

\section{أهداف المستثرقين:-}

هنالك مجموعة من القضايا أو الثبهات والدعاوي يثيرها المستشرقون في كل مرة مع اختلاف طفيف في الصورة بين كاتب وأخر وذلك لجملة

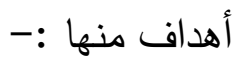

1-الثوشرة على أذهان المسلمين لخلخلة عقيدتهم . r-دفع المسلمين للرد وإنفاذ طاقتهم في ذللك عن العمل والبناء. r-احراجهم بالاتهامات المستمرة ليتصلوا عن بعض حقائق دينهم التي يرغبوا أن بزحزحهم عنها كالجهاد مثنا.

ع-استدراجهم اثناء عملية الدفاع عن دينهم لاعلان صورة غير صحيحة عن الاسلام تخدم الصليبيين كقول بعض المسلمين أن الاسلام يسوي بين

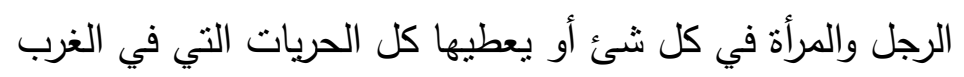

الموضوعات التي درج المستثرقون على تتاولها بمكن الاثارة إلي بعضها

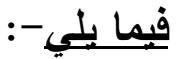
1-التشكيك في صحة العقيدة وكون الاسلام ديناً منزلاً من عند الهه والتشكيك

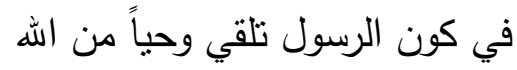

r- تشويه صورة الرسول واصحابه بما يثنير الثك في دوافعهم وأعمالهم.

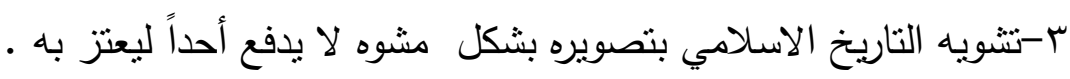

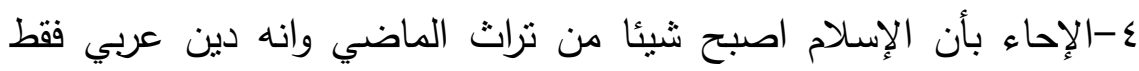
ورجعي لايصلح للنطبيق البوم علاوة على تكبيله للمرأة.

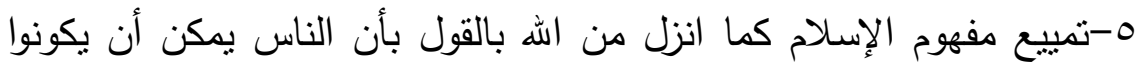

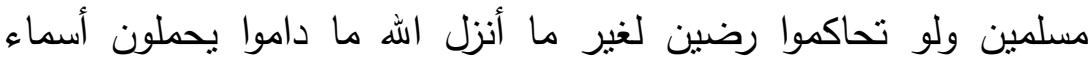
اسلامية وحتى ولو لم يؤدوا العبادات المفروضة . لمبية

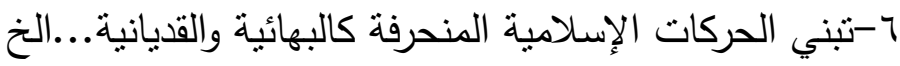


الغزو الفكري والثقافي للامة الاسلامية التددي والاستجابة

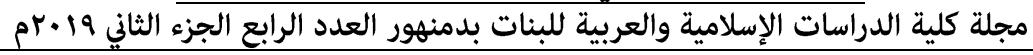

يمكن تقسيم ابحاث وكتب المستشرقين إلى المدارس الاتية: -

1-مدرسة المهاجمين وهي التي تغلب عليها صفة الهجوم على الاسلام وكيل

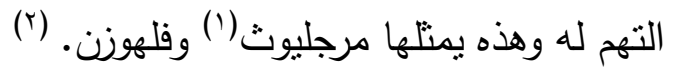

r-المدرسة الحديثة وهي مدرسة تمزج المديح بالغمز واللمز أي تدس السم في

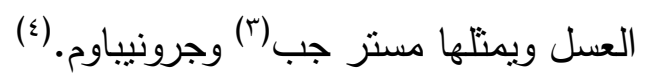

r-مدرسة المديح الخالص ولكنها تصل لذات أغراض سابقاتها في النشويش وجني

والتشكيك للمسلمين ويمنلاها واشنطن إرفنج.(•)

ع-مدرسة التوجيه وهذا التوجيه إما أن تكون ابحاثه موجة للمسلمين انفسهر

للنتكيك والنتويه أو موجه للاول الغربية باعتبارهم جهاز الاستخبارات

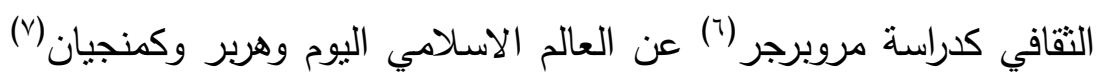

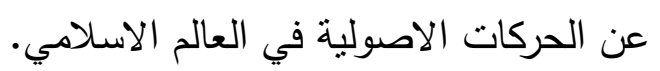

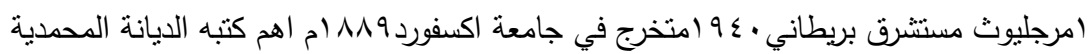

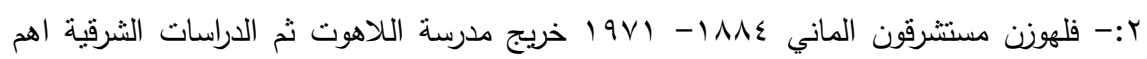

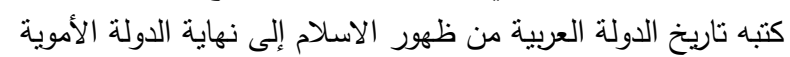

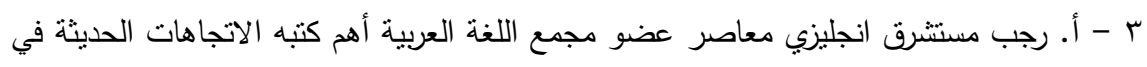
الاسلام

ع- جرونيباوم ،جوستتاف أ.فون مستشرق نمساوي معاصر 9 .9 ام ولا في فينا وتخرج في جامعة فينا ثم برلين ثم هاجر إلى أمريكا حيث كان رئيس قسم الدراسات الثرقية في جامعة كلفورنيا

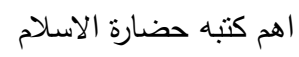
ه - واشنطن ارفنج مؤرخ امريكي معاصر كان وزير مفوض لبلاده في اسبانيا حيث وقف على الانى

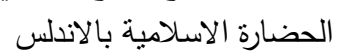

$$
7
$$

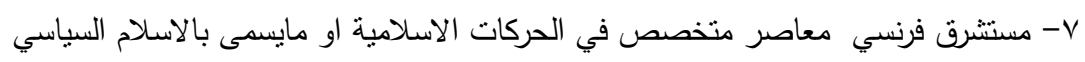




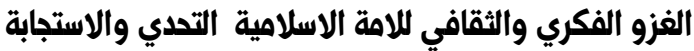

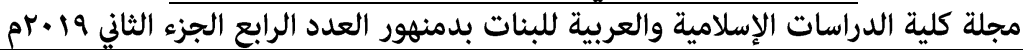

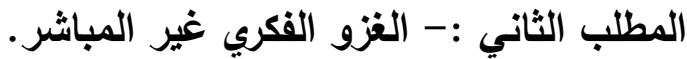

|لعلمانية:-

تعتبر العلمانية أهم أدوات الغزو الفكري والثقافي غير المباشر فما هي

العلمانية؟ معناها كما جاء في القاموس الانجليزي ((دنيوي أو مادي أو ليس اليس بديني أوليس بروحاني )(') وعرفتها دائرة المعارف البريطانية بأنها حركة الهيل اجتماعية تهدف إلى نقل الناس من العناية بالاخرة للعناية بالدنيا فحسب وتحدثت عنها ضمن حديثها عن الإلحاد وقد قسمته إلى نظري وعملي وجعلت

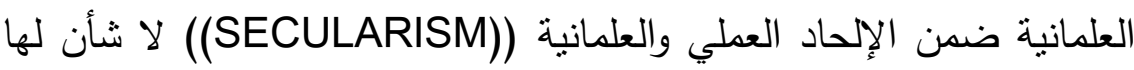
بالعلم كما يزعم بعض دعاتها فالعلم بالانجليزية)(SCIENTISM)كما لا شأن الإنه

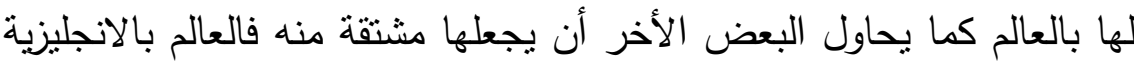
والترجمة الصحيحة لها ((universe)) أو الدنيوية.

وهذا يعني أن العلمانية مذهب فكري اجتماعي يعمل على قيادة الدنيا في جميع النواحي السياسية والاقتصادية والاجتماعية والأخلاقية والقانونية وغيرها بعيدا عن أوامر الدين ونواهيه.تعتبر فرنسا أول دولة أروبية تقيم النظام

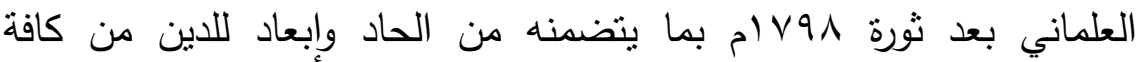
مجالات الحياة بالإضافة لبغض الدين ومعاداته وذلك لان الدين يومئذ لم يكن هو وحي الله الذي نزل على عيسى عليه السلام وإنما تدخلت فيه أيدي الكهان والقساوسة فبدلت وغيرت وأضافت وحذفت وجعلت ذللك دينا يجب الالتزام

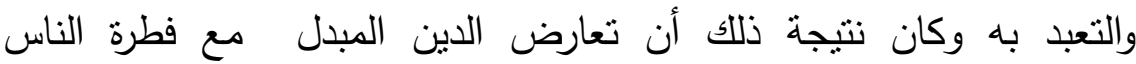
ومصالحهم في دنباهم ومعاملاتهم كما تعارض في ذات الوقت مع حقائق العلم لذا خرج الناس عليه وأقامت الكنيسة محاكم التقتيش في محاولة لرد الناس إليه بالقوة، بعد أن أصدرث البابوية قوائم بالكتب التي يحرم الاطلاع عليها وكل من يعثز عنده على كتاب منها يقدم لهذه المحاكم فحاكمت العلماء وعاقبتهم 


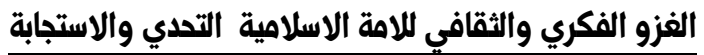

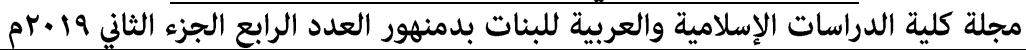

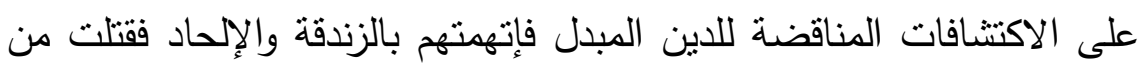
قتلت وحرقت من حرقت كما أخذت في إصدار صلوك الغفران وقرارات الحرمان لابتزاز الناس وأكل أموالهم بالباطل وما لبثت، أن أقامت تحالفاً غير شريف مع الحكام الظالمين وأسبغت عليهم هالات من التقديس والعصدة باليامل

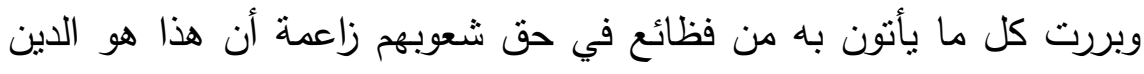

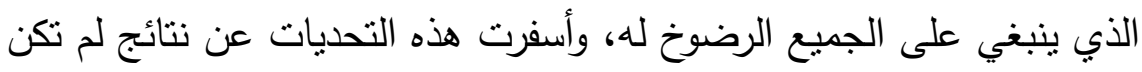

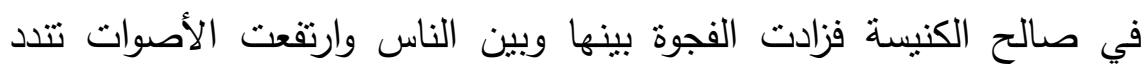

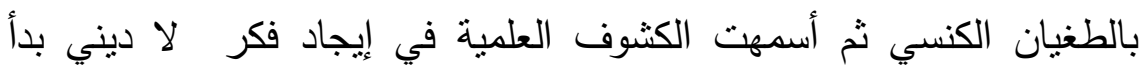
ضعيفاً ثم قوى وانتّد فيما بعد ونتج عن ذللك اتجاهان كبيران أدعى كل منهما

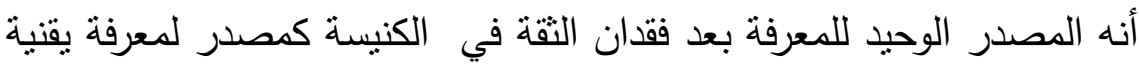

ا-الاتجاه العقلي الذي يدعو لسيادة العقل وهو ما يعرف(( بالعقلانية)) التي

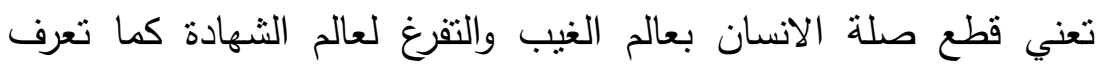

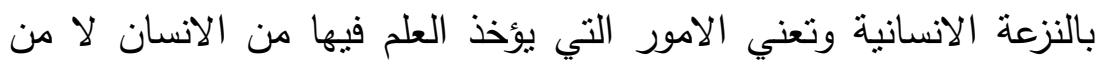
الوحى الرباني وهي نزعة لا دينية،فيحتكم الناس إلي العقل وحده في كل الامور سواء أكانت من اختصاص العقل أم لم تكن.

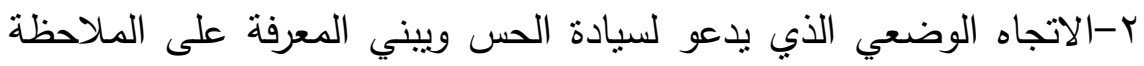

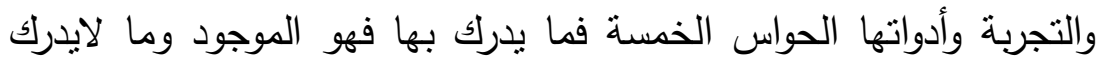
بها فهو خداع ووهم وبذا تم الخروج على هذا الدين الذى يحارب العلم

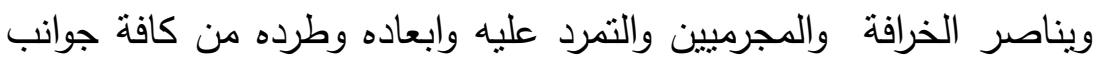

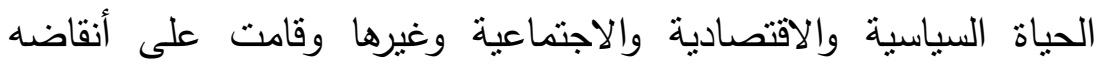
فلسفات إجتماعية مادية تعتمد على هذين الاتجاهين كمصادر للمعرفة وانكرت وجود ما لا يدرك بواحدة منها واطلقت عليه علم ما وراء الطبيعة مهيه ((الميتافيزيقيا)) قاد هذان الاتجاهان إلى الإحاد وانكار وجود الله كما فعل 


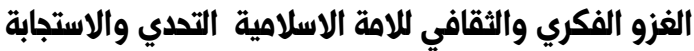

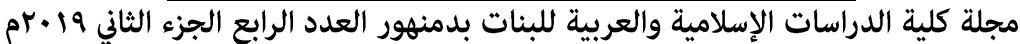

فولتير(') حيث دعا إلى دين جديد هو الدين الطبيعي أما الله فيه فهي الطبيعة نفسها واعتبره إلها جذابأ لا وجود فيه لرجال الدين الذين يأتون بالعقائد الطلسمية التي يستغلون ويستعبدون الناس بها.كما دعا أخرون للقول بأنه اذا كان هنالك إله قد خلق هذا الكون فقدانتهي بذللك دوره فهو يملك الكون ولكن لا يحكمه فالذي يحكم هذا الكون الأن هو الانسان وهو أثبه بملكة بريطانيا التى تملك ولا تحكم ومن هنا جاءت مقولة (ان الانسان هو سبد الوجود)) وشبه آخرون خلق الله للكون بصانع الساعة الذي لم يكن لله تدبير فيها بعد خروجها من يده.

\section{صور العلمانية :-}

\section{افرزت هذه القلسفات الاجتماعية المادية صورتين للعلمانية:-}

ا- العلمانية الملحدة(( المتطرفة )) و هي التى تتكر وجود الله الخالق ولا تعترف به ومن ثم ترفض الدين جملة وتحارب من بدعو إلبه ولعل أبرز صورها تبدو في الثيوعية (( المادية الجدلية الماركسية)) التى كانت سائدة في الاتحاد السوفيتي السابق والحكم بكفرها أمر ميسور لكافة - المسلمين

ץ- العلمانية غير الملحدة(( المعتدلة )) فهي لا نتكر وجود الله وتؤمن به ايماناً نظرياً ولكنها تتكر تذخله في شئون الدنيا وتتادي بعزل الدين عن الحياة فلا يتدخل في الثئون السياسية والاقتصادية والاجتماعية وبقبع فقط داخل جدران الكنيسة وأبرز نموذج لها يبدو في الليبرالية الغربية ( الرأسمالية) في أوربا الغربية وهذه الصورة اشد خطرا على عوام المسلمين لعدم إنكارها لوجود الله وعدم ظهور محاربتها للدين مما يخفي على كثير من المسلمين مخالفتها للإسلام وذلك لضعف علمهم ومعرفتهم الصحيحة به حيث نجد اليوم معظم الانظمة الحاكمة في بلاد المسلمين انظمة 


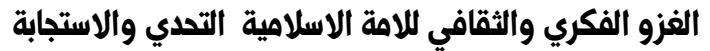

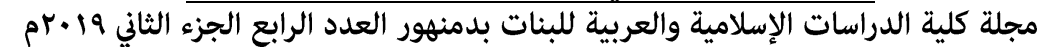

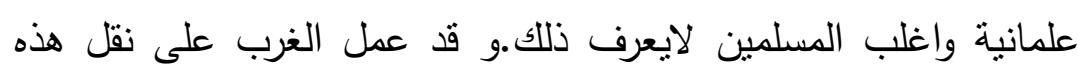

العلمانية لبلاد المسلمين بعدة طرق منها:

1-البعثات الدراسبية:

لعل اشهر البعثات لاوربا تلاك التي أوفدها محمد علي باشا(') لكل من

فرنسا وايطاليا في إطار جهوده لنطوير أوجه الحياة في مصر وكان الغرب قداه لـان عمل على نفس المنوال فمنح بعض الطلاب من دول العالم الإسلامي منح

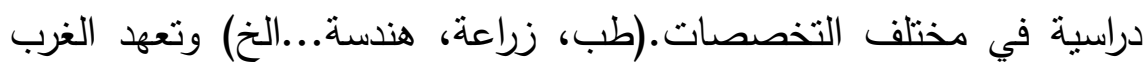

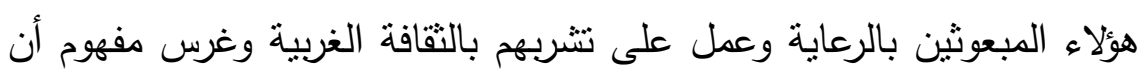

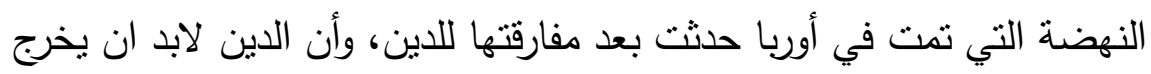

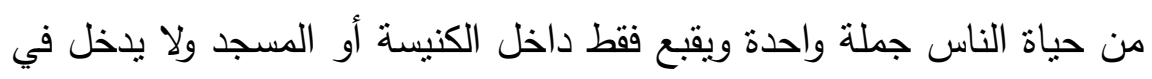

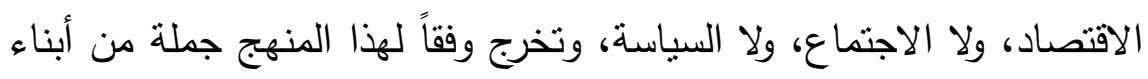

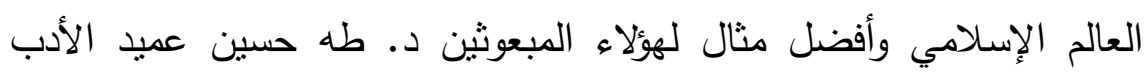

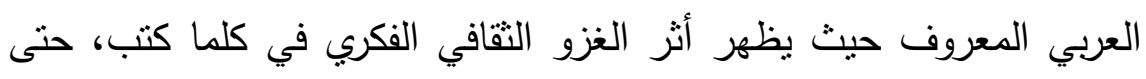
إسلامياته لا تخلو من أثز الغزو الثقافي حيث يبدو تأثره بالمستشرقين فيها واضحاً.

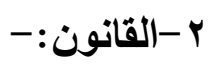

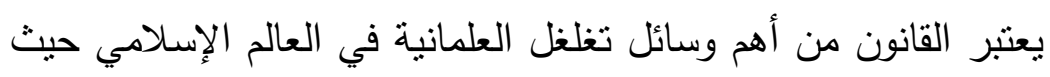

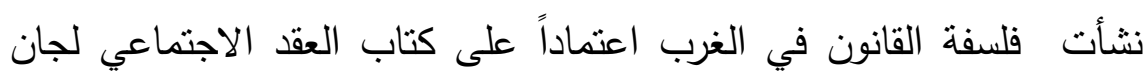

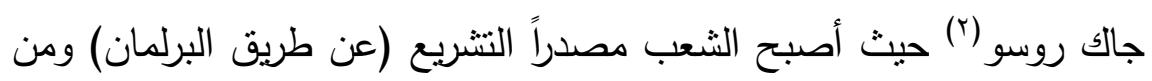

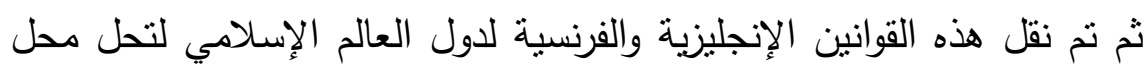

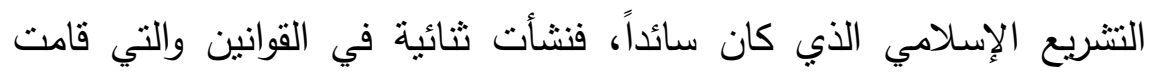

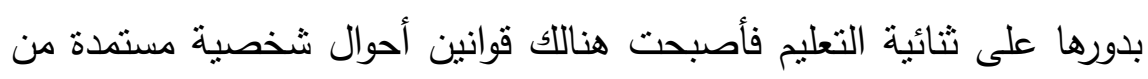
الثربعة الاسلامية وقوانين مدنيه وجنائية مستمدة من القانون الانجليزي او فاهي

ا - محمد علي باثا ألباني الجنسية حكم مصر من قبل الاتراك العثمانيين

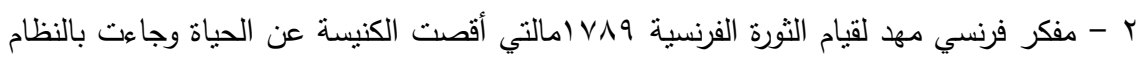

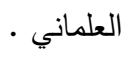




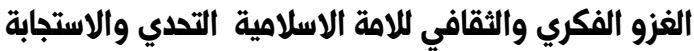

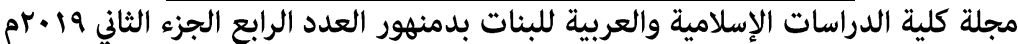

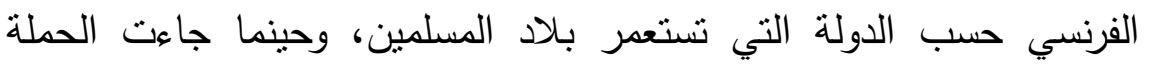

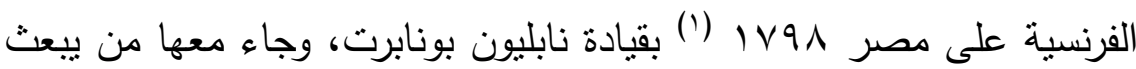

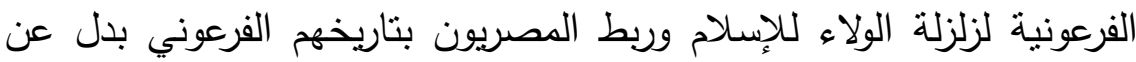

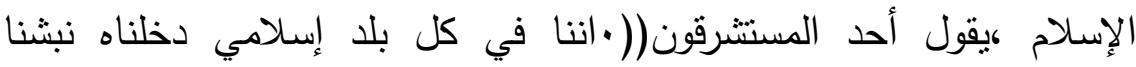

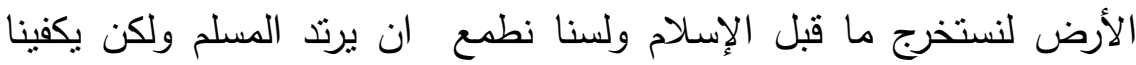

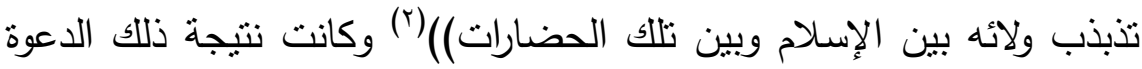
إلى فرعونية مصر على يد د.طه حسين ود.لويس عوض وآخرين ،ثم تلتها

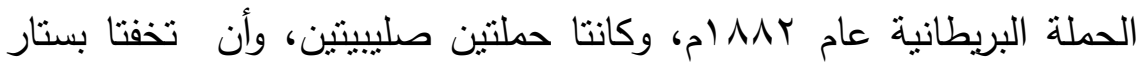
تطوير وتزقية وتتمية مصر فقد كانت أهم أعمال نابليون في مصر إلغاء الثريعة الإسلامية واستبدالها بالقانون الوضعي الفرنسي وحينما احتج علماء

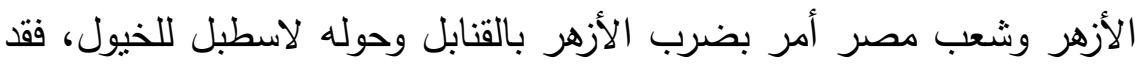
كانوا يريدون تتصير المسلمين ولكن تطبيق حد الردة يحول دون ذلك وأردوا

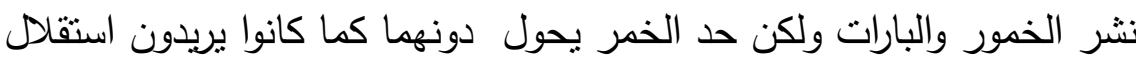
أمول الناس بالربا ولكن تحريمه يحول دون ذلك ولاحظوا أن خطر الثربعة

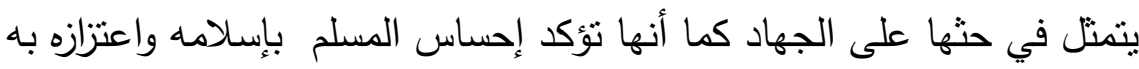
لأنها ربانية وغيرها بضاعة بشرية لا ترقي إلي ما جاء به الله ولذلك عملوا

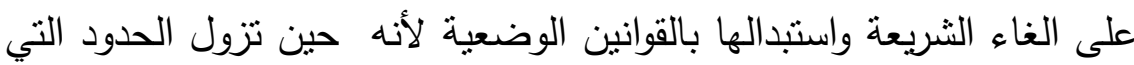

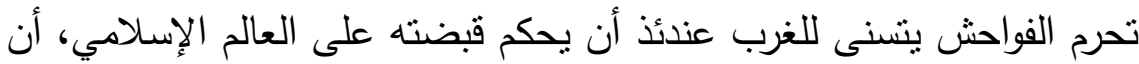

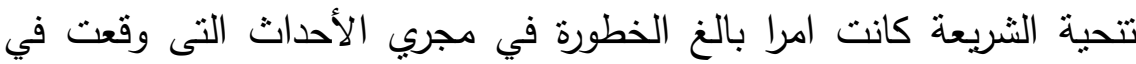

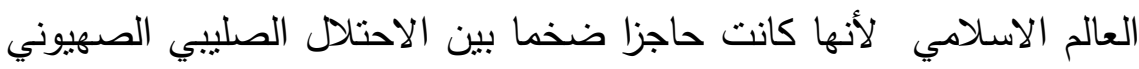
وبين أهدافه الرامية لاحتلال العالم الإسلامي وإحكام السيطرة عليه.

1 - نابليون بونابلرت قائد عسكري فرنسي اخضع كثيرا من البلاد للامبراطورية الفرنسية داخل اوربا

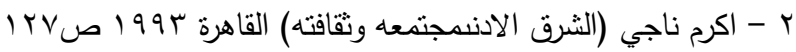




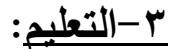

وظيفة التعليم الاساسية هي غرس القيم وتعميقها في نفوس الناشئة بالإضافة إلى عمليات التنشئة الاجتماعية و من بعد ذلك تعمل الثقافة على تجسيد هذه القيم لتكون واقعاً معاشاً الثئ الذي بدل على الإنى الارتباط الوثيق بين

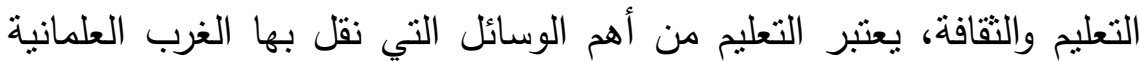
لبلاد العالم الإسلامي وذلك من خلال المناهج التي عمل فيها على تثبيت مفاهيمه للكون والحياة والإنسان((الإنسان سيد الوجود)) ونظرية التطور

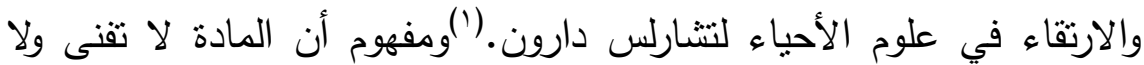

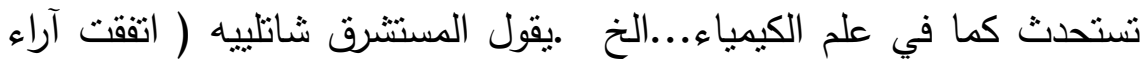
سفراء الدول الكبرى في عاصمة السلطنة العثمانية على أن معاهد التعليم الثانوي التي أسسها الاوربيون كان لها تأثنر على حل المسألة الثرقة مما لهاء يرجح تأثثر العمل المشترك الذي قامت به دول أوربا كلها )(؟.بوالمسألة الثرقية

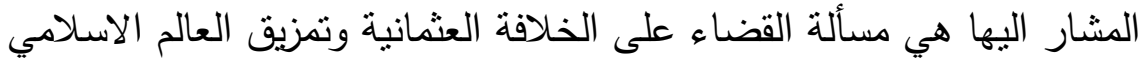
وتوزيع أسلابه على الصليبيين بالإضافة لتخريج أجيال لا يعرفون حقيقة الاسلام وينفرون من الحياة الدينية ولديهم الاستعداد لنبذ الدين يقول كرومرفي ذات المعني ( أن التتسع في التعليم الابتدائي والثانوي في مصر أنتج أنجاهاً

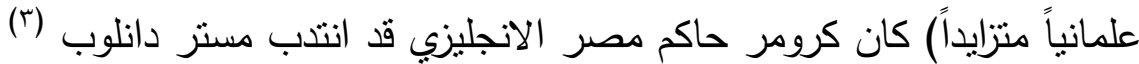

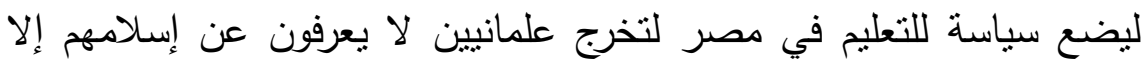
الثبهات التي يثيرها المستشرقون ولا يعرفون عن تاريخهم إلا أسوأ ما فيه بينما

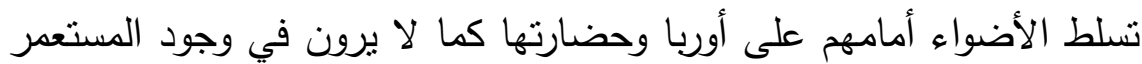
دافعاً إلى الجهاد المتصل بالعقيدة مباشرة أما الجهاد السياسي فأمره أهون بالنسبة للمستعمر فهو يتم عبر لقاءات ومفاوضات ومساومات وفي كل مرة يخرج المحتل الغاصب منتصراً على المغلوبين وكان المطلوب أيضاً تخريج

I - عالم احياء يهودي زعم ان الانسان نتاج تطور الحيوانات الدنيا من امبييا وزواحق وثديات

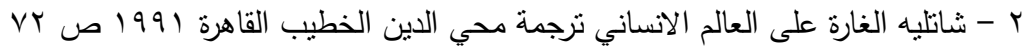

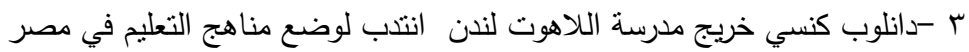




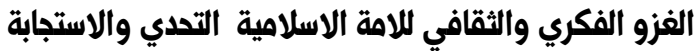

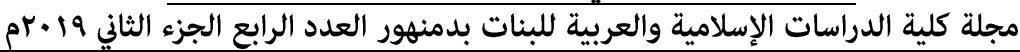

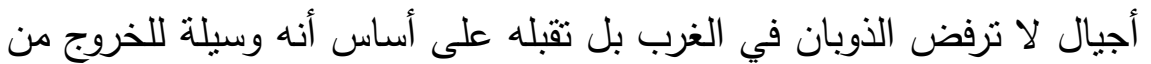
التخلف والسير نحو الحضارة والتقدم والرقى وذلك لا يكون إلا بسياسة تعليمية

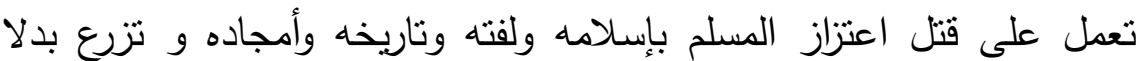

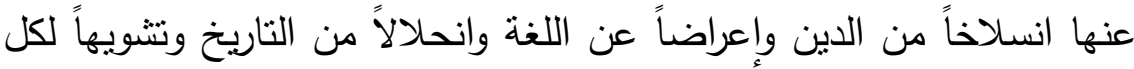

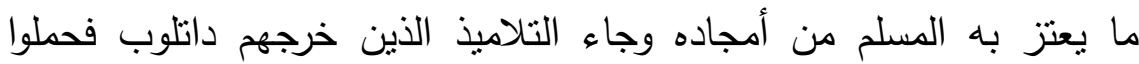
رسالة الانسلاخ من الدين والذوبان في الغرب فقتحوا قلوبهم وعقولهم لما ييثه

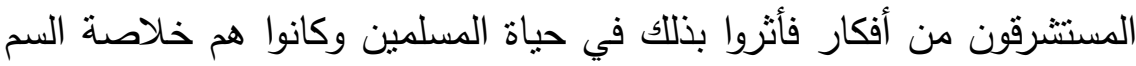
الصليبي الصهيوني.

فالطالب الذي يتخرج من هذا المنهج لم يعرف دينه من مصادره الإسلامية الصحيحة ولكن أعطيت له صورة مشوهة عنه وعن أهدافه وعن هن لهن آثاره في الأرض ولم يعرف من تاريخه إلا الاسود منه الذي أُبِرز أمامه بينما

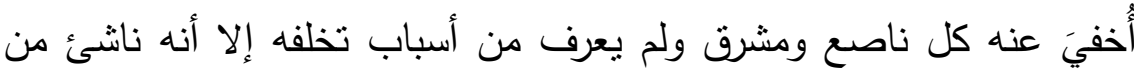
الدين ومن الإسلام بصفة خاصة ، وأن المَخرج هو إنباع أوربا والتخلي عن إنى

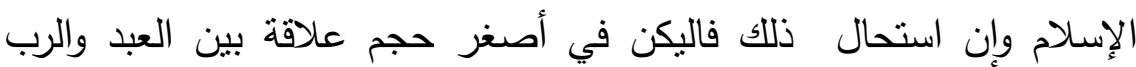
محلها القلب ولا صلة لها بواقع الحياة فلا يرجع له المسلمون في كل صغيرة

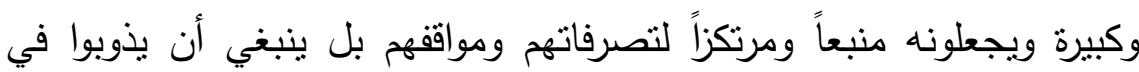
الحضارة الغربية فلا تكن لهم شخصيتهم المستقلة المتميزة المستمدة من دينهم والتي يقفون بها في وجه الغرب وأطماعه الاستعمارية ودعوته للعقلانية التي تقطع كل صلة للإنسان بعالم الغيب والتقرغ لعالم الثهادة في حدود ما تدركه

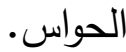

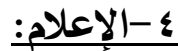

يقوم الإعلام علي مخاطبة الشعور والأمن عبارة عن شعور يحس من خلاله الفرد بالأمان للإعك فأن مخاطبة هذا الثعور من خلا وسائل الأعلام

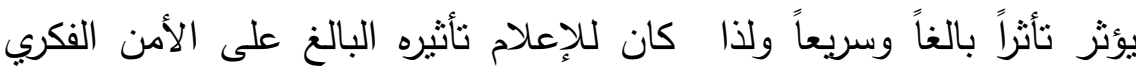

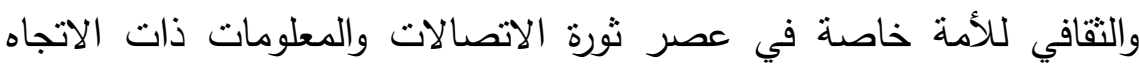
الواحد والتأثير السلبي علينا والمخطط له من قبل الأعداء والتي تتم صناعته 


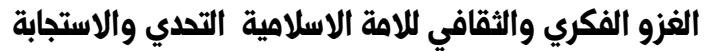

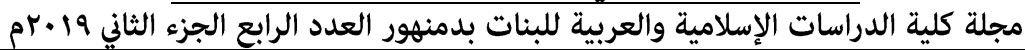

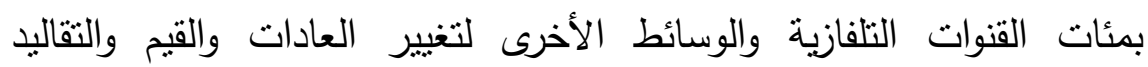
والمفاهيم لدي الثعوب المستهلكة لهذه المواد الإعلامية والثقافية خاصة دول العالم الإسلامي فتعيد تشكيل نقافتها وقيمها الاجتماعية وبذا أصبح الإعلام أهم وسائل الغزو بوسائطه الجذابة وتتكيله لاتجاهات الرأي العام الثئ الذي الذي التئي

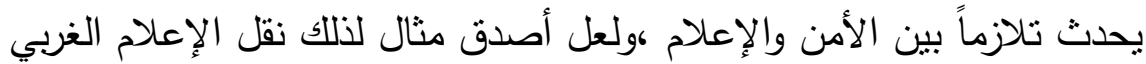
لمشكلة دارفور من المحلية للعالمية في زمن وجيز مقارنة بمشكلة جنوب الإعن

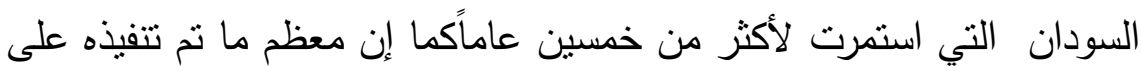

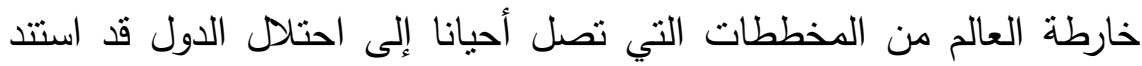
فيها على قاعدة متينة من التأييد العالمي بعد نشكيل وبلورة الرأي العام في لهي اتجاه ذلك التأييد والذي تم من خلال استراتيجيات وخطط إعلامية محكمة واعتماد وسائط ذات خصائص تكنلوجية منطورة وكادر فعال ذو قدرات عالية كويعتبر الغرب الإعلام هو وسيلته المنلى للغزو الفكري والثقافي وذللك بفرض القيم الغربية والفكر الغربي في ظل انفتاح الحدود والفضائيات وعدم قدرة دول لعابل العالم الإسلامي لمنافسة الوافد عليها من الثقافات والأفكار والقيم والعادات التي تصادم الموروث الثقافي الفكري لها مما يعني طبيعية العلاقة الوثيقة بين الغزو

$$
\text { الفكري الثقافي و الإعلام. }
$$

\section{متى يبلغ البنيان يوماً تمامه ** اذا انت تبنيه وغيرك يهدمه} عليه فالإعلام سلاح ذو حدين يمكن أن يبنى كما يمكن أن يهدم وقد

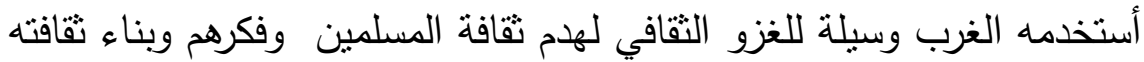

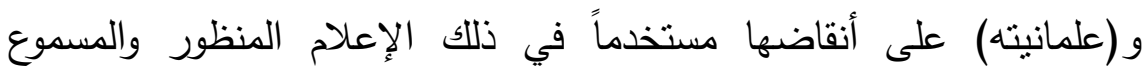
والمقروء والوسائط الالكترونية ((الصورة والصوت والصحف والدوريات والمجلات والمسلسلات...الخ ) مركزاً على نظرية الطرق الاعلامي لتنبيت مفاهيمه وقيمه كالإباحية وبهيمية الانسان ..الخ 
لم يكره الإسلام أحداً للاخول فيه الثيء الذى جعل بلاد العالم

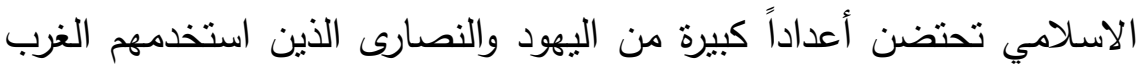
وسيلة لنشر العلمانية وذلك للتشابه فى الاعتقاد الديني فيما بينهم ولمعرفتهم الدقيقة بمجتمعاتهم فقد كانوا أول من حمل راية العلمانية في دول العالم

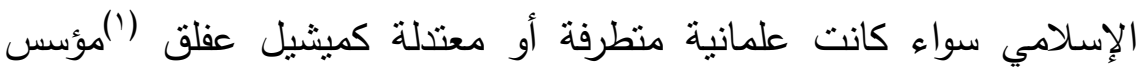

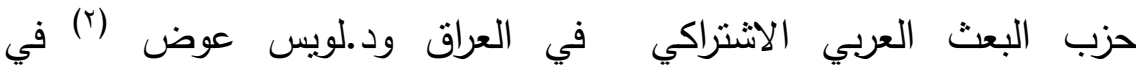

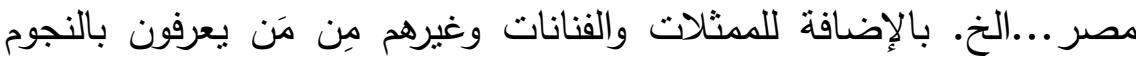
وجلهم من نصارى الثام.

\section{צ- الفرق الباطنية:}

تدعى هذه الفرق أن لنصوص الدين الإسلامي ظاهراً وباطناً لا تعبر عنه عبارات اللغة وإنما يعرف بالذوق والإشراق والعرفان من أصحاب العلم لإن اللاني.

وهي فرق تتنمي للإسلام أسماً ولكنها خارجة عليه بإجماع المسلمين

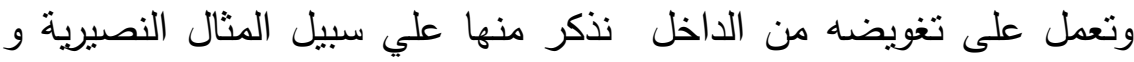
العلويين في سوريا والدروز في لبنان وغيرها، فقد مكنت هذه الفرق للاستعمار

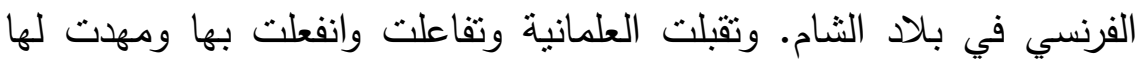
الطريق لتكون واقعاً يعيشه المسلمون في تلك البلاد.

\section{V- الاقتصاد والتجارة:}

كان للاقتصاد والتجارة دور كبير في الغزو الغربى للعالم الإسلامي والتمكين لثقافته وقيمه، وذلك عن طريق استخدام الربا في المصارف وبعدها في كل النشاط الاقتصادي بعد تتحية الثريعة الاسلامية التي تحرم الربا وانتشر بعد ذلك المرابون من اليهود والنصارى في بلدان العالم الاسلامي بلي وعملوا على نهب ثروات البلاد وتصديرها للخارج كما جعلوا البلاد سوقاً 


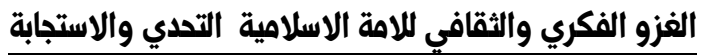

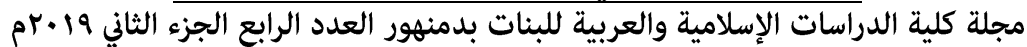

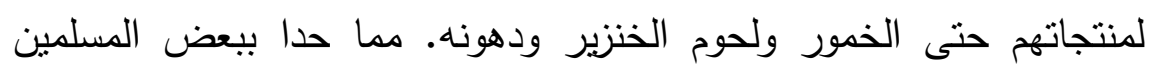
ليمارسوا الربا والغش التجاري بصوره يومية ولا برون في ذلك حرجاً.

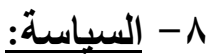

تعتبر السياسة من الوسائل التي عول عليها الغرب في نشر العلمانية

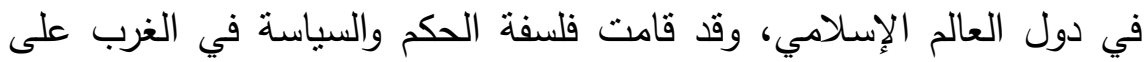
أساس الديمقراطية غير المباشرة وذللك بعد الرجوع للتراث اليوناني القديم قبل ميلاد المسيح وأخذ النظام الديمقراطي عن أثنيا. والديمقراطية تعني حكم

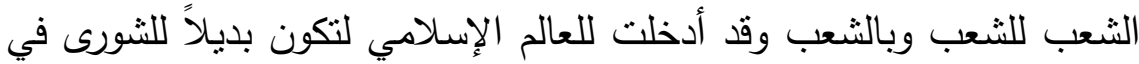
فكر الاسلام السياسي وقاموا بأنشاء احزاب في كل دول العالم الاسلامي على لهی مفاهيم الوطنية والقومية كرايات يتجمع حولها الناس بعد أن كان يلتفون حول بلاه راية لا إله إلا اله لتعمل هذه الاحزاب على تمزيق الدولة بالتتازع فيما بينها ويسود عدم الاستقرار وينفرط عقد الأمن ولا تتفرغ هذه الدول للبناء والتتمية

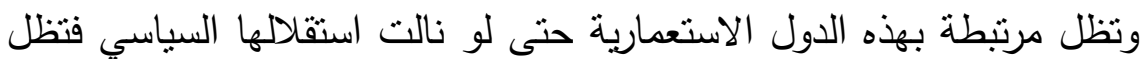
مستعمرة اقتصادياً وثقافياً.

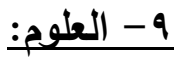

بالرجوع لتاريخ العلوم في أوربا يتضح لنا أنها نشأت في الغرب بشقيها

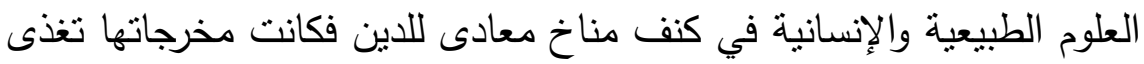
هذا الاتجاه خاصة العلوم الإنسانية كعلم النفس والعلوم السياسية وعلم الاجتماع والفلسفة والتاريخ والتربية وغيرها، وانتقلت هذه العلوم بما تحمل من الإهن ظلال لمحاربة الدين والحط من قدره ودوره في الحياة بذات المفهوم للعالم الاسلامي لتؤطر للفصل بين الحياة والدين وتعزيز البناء العلماني في النفوس ونئ ونئ والعقول مما يحتم علينا عدم أخذها جملة واحدة وإنما يجب تمحيصها لاسيما

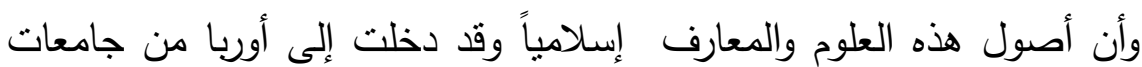
الأندلس في قرطبة وغيرها تاريخياً. 


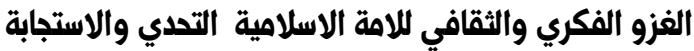

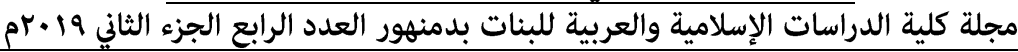

المطلب الثالث : الغزو الموجه عبر الخدمات الانسانية والفنون والأعراق: لم يكن الغزو الفكري والثقافي للعالم الاسلامي مباشراً فقط وانما اتخذ ايضا اشكالا غير مباشرة كما رأينا وموجهة أيضاً عبر عدة منافذ على النحو

اولا العمل الانساني الطوعي:-عندما غادر الاستعمار دول العالم الاسلامي تزك فيها كثيراً من القنابل الموقوتة اما مشاكل في الحدود بين الدول او وجود أقليات عرقية واثتية أو طائفية داخل الدولة الواحدة ثم لا بلبث أن ياخذ في اثارة وتزكية نزاع الحدود أو النفخ في الاقليات واثارة النعرات القبلية والطائفية وتقديم المساعدات الفنية والمادية والعسكرية لها لتحويل النزاع لصراع مسلح أو دعم الاقليات لتخرج على سلطان دولها وتقاتلها ثم يعمل بعد ذلك على معالجة افرازات هذا الصراع من نزوح وجوع ومرض وفقر بمنظماته الطوعية بعد ان بسلط الضوء عليها اعلاميا ويصور ماساة الناس والظرف ماف الذي يعيشون فيه والاحتياجات العاجلة لهم فتسرع هذه المنظمات في جمع التبرعات من الخيربين لإنقاذ هؤلاء الناس بالإضافة لما تقدمه منظمات الامم

لاشك أن المتأثرين بهذه الحروب من نساء واطفال وعجزة وهم قد غادروا ديارهم وفقدوا مصادر دخلهم فهم بحاجة إلى المأوى الذي يقيهم الحر والبرد كما هم بحاجة الي مياه نقية وحمامات لكي لا تتنشر الاوبئة وسطهم وغالبا ما يتم تجميعهم في خيام في شكل معسكر يضم هولاء النازحين او اللاجئين بالاضافة لتوفير الكساء والغذاء في شكل وجبات جاهزة في بادي الامر ثم توزبع لهم فيما بعد مواقد ومواد خام لتقوم كل اسرة بعد ذلك بطهي طعامها والذي غالبا ما يكون قريباً مما كانوا عليه في موطنهم.

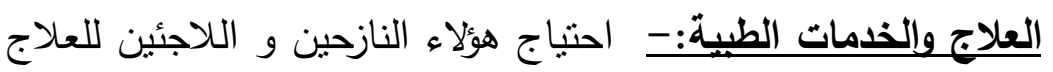
والعناية الطبية لايقل عن حوجتهم للمأكل والمشرب والمأوي وذلك للأثار النفسية والبدنية لهذا الصراع الثئ الذي يدفع المنظمات الطوعية الغربية لعمل 


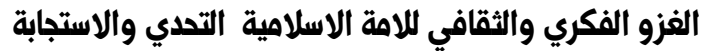

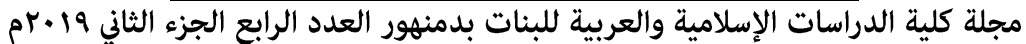

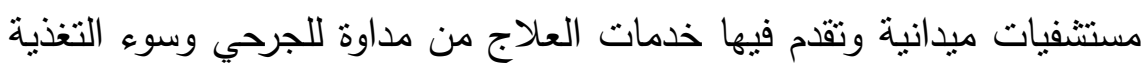
والاكتئاب وغيرها وتوفير الادوية والمحاليل الوريدية والمستهلكات الطبية مجاناً.

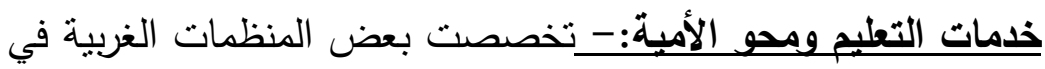

تقديم خدمات التعليم للأجئين والنازحين في معسكراتهم وتتكفل بتوفير كل معينات العملية التعليمية من معلميين وكتب وكراسات وغيرها مع تعهة كامل للتلاميذ ورعاية صحية وتغذية لهم. أن خدمات الاعاثة والعلاج والتعليم التي تقدم لهولاء النازحين واللاجئين تقدم من خلالها الدعوة للتتصير بطريقة مباشرة أو غير مباشرة فتقام مثنا حلوى للأطفال ويقال لهم هذه حلاوة المسيح تقدم أخرى مرة المذاق حامضة الطعم ويقال لهم هذه حلاوة محمد إن هذه الخدمات نتؤثز في نفوس بعض هض هره الناس فيبدأ بالإطراء عليهم يقول أحد النازحين بعد أن تلقي الاغاثة الامريكية

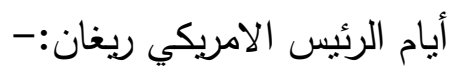

يسلم لينا ريغان خل الثعوب تتضامن بس فيه عيباً واحد بس بالرسول ما بيامن

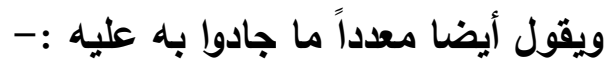

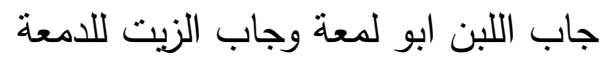
كما ان الخدمات هذه التى يقدمها الغرب تظهره في اعين البسطاء من المسلمين وما اكثرهم بالمظهر الانساني ويحاول بذلك الغرب ان يثتبت في

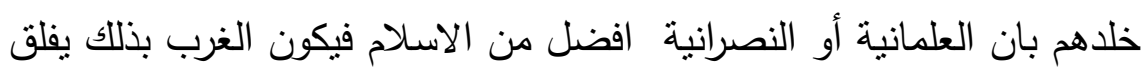

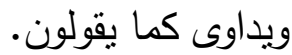

لاشك ان هذه الخدمات نزلزل قناعات بعض الناس فيتم تتصيرهم ويتزتب على ذللك خلق كيانات مسيحية وسط المسلمين لتصبح بؤرا للتؤتز تؤدي لتأجيج الصراع الديني الطائفي مستقبلاً وخلق عدم الاستقرار السياسي والاجتماعي ويعمل على تعطيل التتمية في الدول الاسلامية لتصبح رهينة

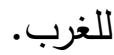




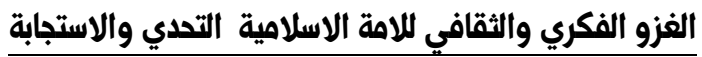

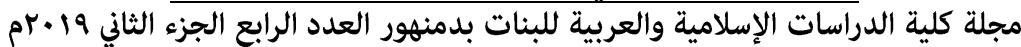

r ا المسرح والسينما:

يعتبر المسرح من أهم وسائل التعليم غير المباشر والمؤثر في الوجدان وقد قيل قديماً (اعطنى مسرحاً أعطيك أمة) وقد وظف أعنى الغرب المسرح كما وظف السينما في بلاد المسلمين ليخرج أمة علمانية وذلك بزرع مفاهيمه

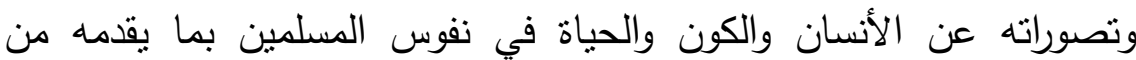

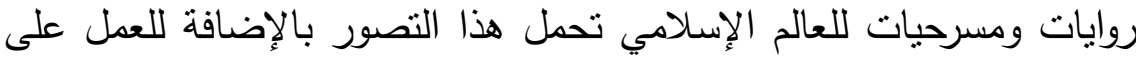
تصويره للإسلام والأديان عموماً بأنها ضد الفنون والمسرح ـ ولذا الصبات أصبح كل الذي يقدمه على خشبة المسرح والسينما يعززان للعلمانية والقيم والمفاهيم الغربية بنشر الصور الخليعة العارية التي تخدش الحياء وتدعوا للاباحية

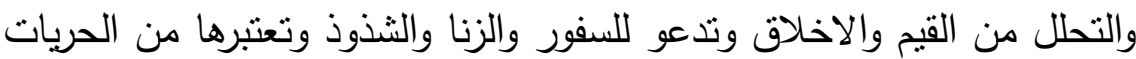

يعكس الأدب والثعر وجدان الأمة وبيرزان تقدمها وانحطاطها ويعبران

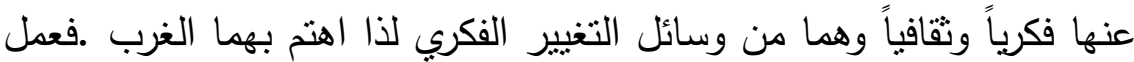
على حث ودفع الادباء والثُعراء على توظيف الأدب والثشعر العربي الحديث

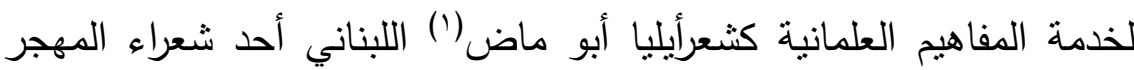
حيث يقول في إحدى قصائده مثناً:-

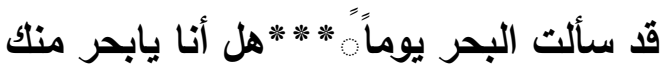
اصحيح مارواه أنهم عني وعنك *** ضحكت أمواجه مني وقالت لست أدري وعلام لست أدري لست أدري **** وكل ما أدريه اني لست أدري يروج هذا الثاعر بهذه الابيات لفلسفة الثك التي قال بهالفيلسوف

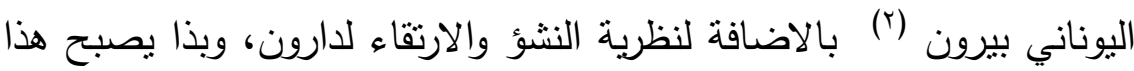

إيليا أبو ماضي شاعر لبناني معاصر مسيحي هاجر الى امريكا وكون مع جبران خليل حبران

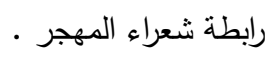

r بيرون فيلسوف يوناني سفسطائي صاحب مدرسة اللادرية وقد تصدى له الفيلسوف سقراطفحض

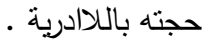




\section{الفزو الفكري والثقافي للامة الاسلامية التددي والاستجابة}

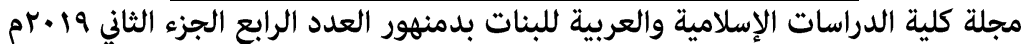

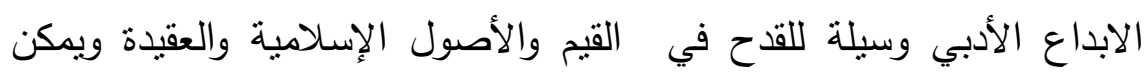

للعلمانية في العالم الإسلامي.

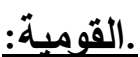

مشتقه من كلمة القوم وهم الجماعة وتعني الذين ينتسبون لجد واحد أو عرق واحد أو دم واحد ويتحدنون لغة واحدة وثقافة واحدة، ولما كان العالم

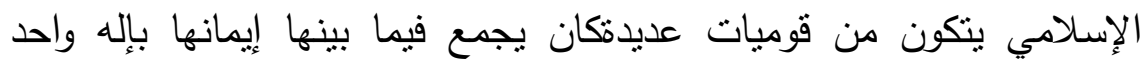
ورسول واحد وكتاب واحدودين واحد في كنف دولة واحدة هي الدولة الغثمانية غير أن الغرب عمل على تحريض هذه القوميات على الإمبراطورية العثمانية.

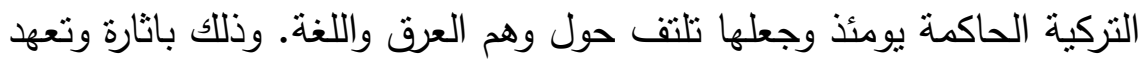
ورعاية الثعور القومى وتزكيته بين مكونات الامبراطورية ليعمل على تفنتها

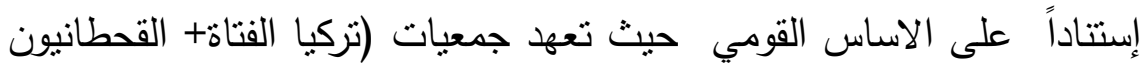
دعاة القومية العربية +...الخ).في لندن وباريس • وحينما وصل رجال الاتحاد والترقي للسلطة في نركيا عملوا على تتريك القوميات الاخرى مما أدى الى ولى ولى

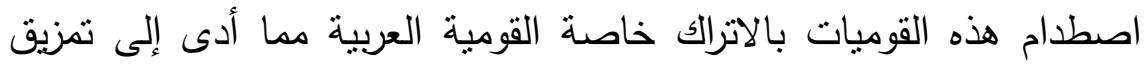
هذه الإمبراطورية إلى دويلات على الاساس العرقي اضعة خاضعة للاستعمار الفرنسي او الإنجليزي ولم ينالوا استقلالهم كما وعدوا بذلك قبل الحرب ولكنه الإسي استبدلوا سيد بسيد(( فاصبحوا كما يقولون كالمستجير من الرمضاء بالنار )) ولم

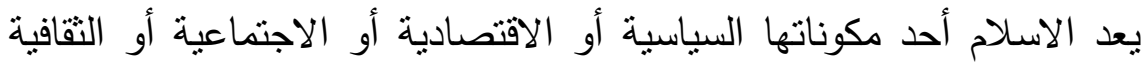

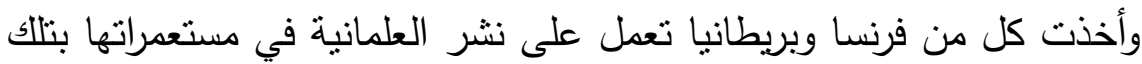

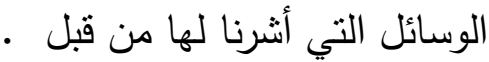




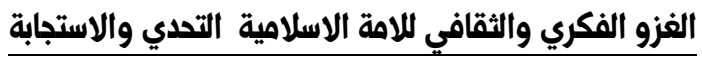

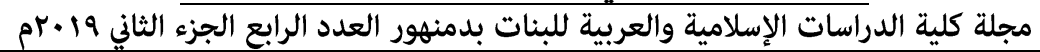

الفصل الثالث

\section{مواجهة الغزو الفكري}

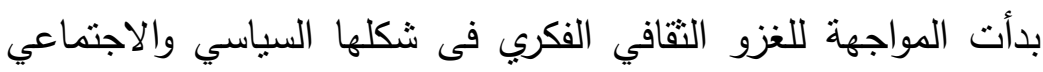

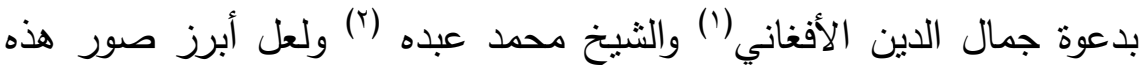

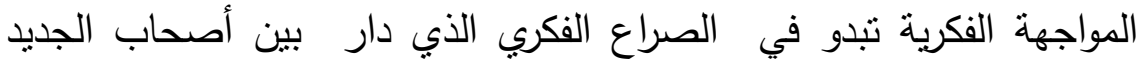

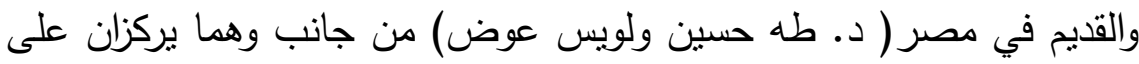

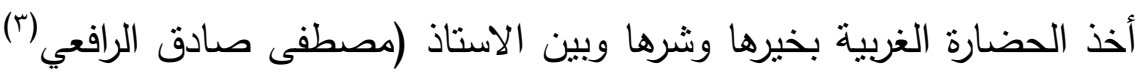

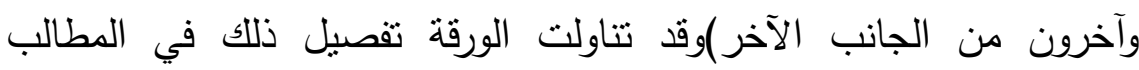
الآتية :-

\section{المطلب الاول : المحافظة على هوية الامة وتراثها:-}

ان اولى خطوات مواجهة الغزو الفكري ينبغي ان تكون بتعريف المسلم بحقيقة دينه الذي يقوم ابتداءا على اساس العبودية الخالصة لله بتوحيد الالوهية

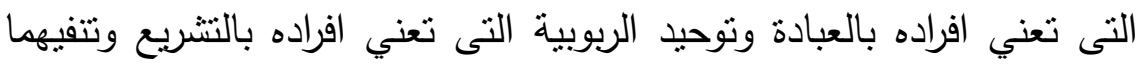

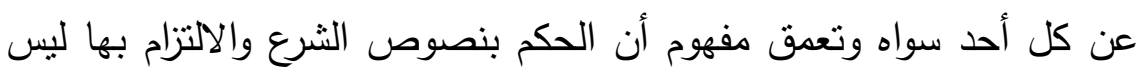
الا وجها من اوجه افراد الله بالعبادة ومن ثم فهي ركن اصيل في الاسلام

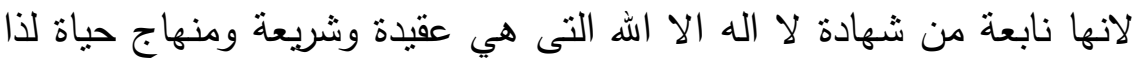

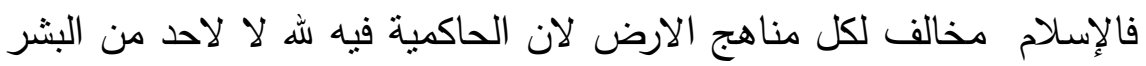

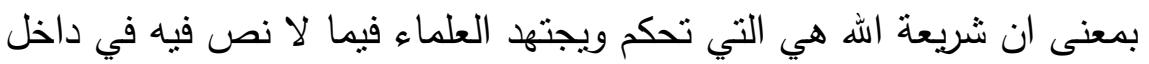

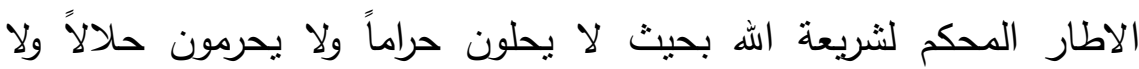

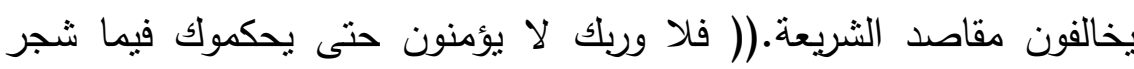

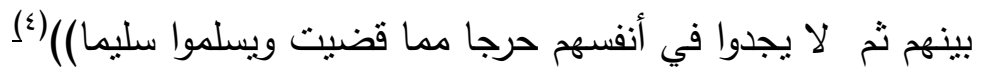

1 - جمال الدين الافغاني من افغنستان نولى الدعوة لاخذ ما لا يتعارض مع الاسلام من الحضارة الغربية r - أحد علماء الازهر قاد عمليات الاصدلاح الاجنماعي r - مصطفى صادق الرافعي عالم مصري تصدى لدعاوى طه حسين في قوله بنحل الثعر العربي الإدي في كتابه تحت راية القرآن

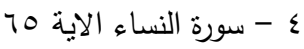


الغزو الفكري والثقافي للاهة الاسلامية التددي والاستجابة

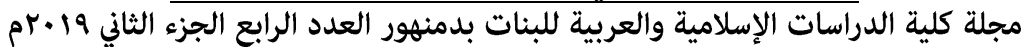

(وان احكم بينهم بما أنزل اله ولا تتبع أهواءهم واحذرهم أن يفتنوك عن

بعض ما أنزل إلبك)(ان) (1)

(وما كان لمؤمن ولا مؤمنة إذا قضي الله ورسوله أمرا ان يكون لـهم

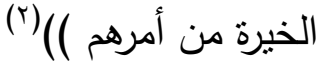

(أفحكم الجاهلية يبغون ومن أحسن من الله حكماً لقوم يوقنون)(آ)(أ) الاسلام ليس شيئا مختلفا عن الحياة بالنسبة للمسلم الحقيقي

(( قل إن صلاتي ونسكي ومحياي ومماتي لله رب العالمين لا شريك

(ई) $((\Delta$

فالإسلام بالنسبة للمسلم يشمل كل لحظة من لحظات حياته وكل

تصرف وكل عمل وكل شعور بالاضافة لأن تكون الحياة بتعاليمه وتوجيهاته ومبادئه وقيمه ت تشكل واقعه المعاش بكل مجالاته السياسية والاقتصادية والاجتماعية والفكرية والروحية فهو منهج رباني ينشئ الانسان الصالح ويحرره من عبودية غير الله. حقيقة أن الفترة المثالية الاولى التي ارتفع فيها المسلمون عن ذواتهم وحققوا نلك البطولات التاربخية النادرة قد انحسرت وبقية الصورة العادية للإسلام ولكنها أنشات المنهج التجريبي في البحث العلمي الذي اصبح اساس نهضة أوربا التى لم ترتقع للافق الانساني الذي كان عند المسلمين فعملت علاوة على ما بفيد البشرية عملت ايضا على ما دمرها روحياًرخلقيا وماديا كما أنشا هذا الاسلام العادي مفهوم الامة بمعنى المجموعة من الناس اللذين يلتقون في عقيدة مشتركة ولكن اوربا حينما اقامت مفهوم الامة لم تقمه على العقبدة في الله كما هو الحال في الاسـام ولكن اقامته على الاساس القومي ولذا احدثت من الثر اكثز مما أحدثت من الخير من خلال الصراع والحروب والاستعمار والاستعباد لغيرها من الثعوب.

\footnotetext{
1 - سورة المائدة الآية ب؟

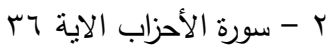

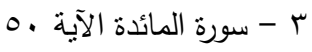

ـ - سورة الانعام الآية 1
} 


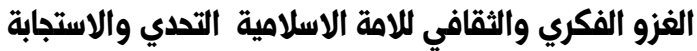

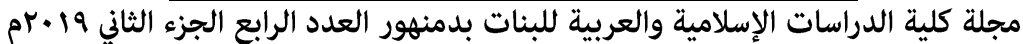

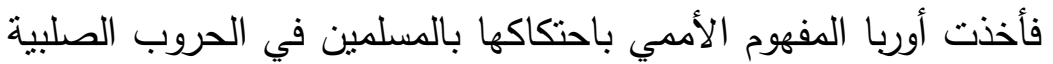
، فخرجت بذلك من حياة الاقطاع حيث السبد الاقطاعي يحكم أقطاعيته بصورة شموليه تتمنتل جميع السلطات فى يده (التشريعية والتنفيذية والقضائية) وتتفصل كل اقطاعيه عن غيرها من الاقطاعيات انفصالا كاملا علاوة على انفصال العاملين فيها عن الكيان الحقيقي للانسان اذ هم عبيد لهذا الاله الصغير صاحب السلطان المطلق عليهم

الاسلام يعتبر أول نظام واقعي طبق في واقع البشر محاولا اقامة ملكوت الله في الارض وازالة كل طاغوت سواء كان صنما بعبد في عالم المحسوسات أووثناً يؤله في عالم المعنوبات او كان فردا او قبيلة او امة او كان عرفاً مستمدا من باطل الناس او كان قوة مادية او اقتصادية او سياسية) ولم يرجئه إلى الدار الأخرة كما فعلت المسيحية واقامت في واقعها القانون الروماني الذي اباح استرقاق الامم والثعوب والاقطاع ثم الرأسمالية.و الاسـلام هو القوة الوحيدة في التاربخ التى فتحت البلاد دون ان تستعبد العباد((متى استعبدتم الناس وقد ولدتهم امهاتهم أحراراً) (') فكفلت للناس حربة العقيدة وحرية العبادة ولم تحجب عن البلاد المفتوحة شيئا مما تملكه من العلم والخير اعتزازا بالغلبة والسلطان.

التأصبل:-

هو الرجوع إلى الأصل وهو الوحي (القرآن السنة) واقامة الحياة عليهما وهو إذن في جوهره بصادم العلمانية وهو ما بطلق عليه الغرب الأصولية الإسلامية وقد كانت دفعته الفاعلة على يد كوادر المدرسة التربوبة في مصر ( الاخوان المسلمين )

كالثيخ عبدالقادر (r) عودة ، الذي تخرج رحمه الله في كلية الحقوق بجامعة القاهرة التي كانت تدرس فيها القوانين الفرنسية ثم عكف بعد تخرجه على البحث والدراسة في التشريع الإسلامي فكانت ثمرة ذلك هذه الاسفار 1 - فالها عمر بن الخطاب لعمرو بن العاص حينما اعتدى ابن الاخير على أحد اقباط مصر وقد

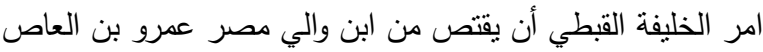

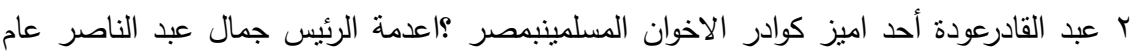

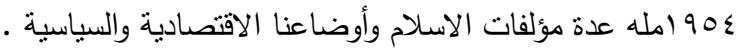




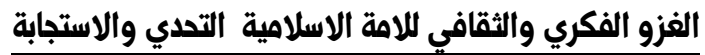

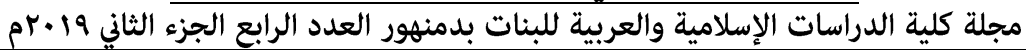

القيمة الاسلام وأوضاعنا القانونية والتشربع الجنائي في الاسلام وغيرها ،وهذا يعنى أن التأصبل يتطلب المعرفة التامة بعلوم الغرب في التخصص المعنى من جانب والتمكن مما يقابله في الفكر الإسلامي من جانب آخر واستتاداً على هذا المنهج بمكننا أن نواجه هذا الغزو في محاوره المختلفة في الاقتصاد

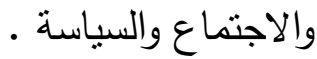

\section{المطلب الثاني :- التعليم المنهجي الاسلامي:}

لما كان التعليم من أهم المحاورالتي ركز عليها الغرب في نقله للعمانية لدول العالم الاسلام ينبغي علينا أيضاً أن نركزعليه في مواجهة هذا الغزو وذلك بالآتي :-

ا ـ وضع مناهج التعليم وفقاً للتصور الإسلامي للكون والأنسان والحياة r. تصميم المناهج لتعمل على تعزيز الايمان في نفوس الناشئة والتلاميذ والطلاب وغرس القيم الإسلامية الفاضلة ومحاربة الجهوية والعنصرية والتأصيل لقيمة أهمية العمل والزمن في حياة المسلم . r. الدقة في اختيار المعلم الكفء الذى ينفذ المنهج فنياً والعمل على إعداده وتدربيه في المراحل الثلاث الأساس والوسطى والثانوي بالإضافة

$$
\text { لمرشدات رياض أطفال. }
$$

ع. تحقيق المكانة الاجتماعية المرموقة لمعلم.( راجع تجربة الاتحاد السوفيتي + ميركل في ألمانيا) وتوفير احتياجاته المادية. ه. الاهتمام بالنشاط اللاصفي للتلاميذ وربطه بالصفي. جـ الاهتمام بتعليم الرحل واليافعين والمعوقين. V. الاهتمام بالوسائل التعليمية وخاصة التعليم الاكتروني. A. الموازنة بين التعليم الأكاديمي والفني. 9. ضبط المدارس الأجنبية والخاصة ومراقبة الأداء بها وإلزامها بتدربس اللغة العربية والتربية الإسلامية وتاريخ وجغرافية وادي النيل وأن يكون كل معلميها وطنيين توافق عليهم الوزارة. 


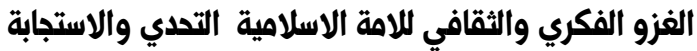

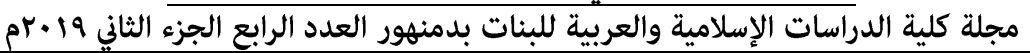

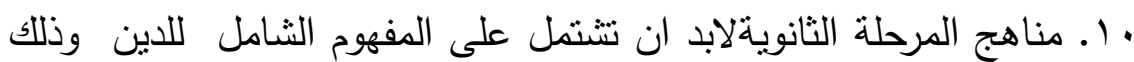
بتوضيح المفهوم الصحيح للاسلام بالإضافة للتعربف بالثيعة والسلفية الجهادية و العنصرية والجهوبة والتتبيه علي خطورتها جمبعاً كمفاهيم

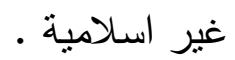

ا ـ التدرج في المنهج بين المراحل الثلاث وإبراز ضرورة وأهمية المرحلة الوسطي بين الأساس والثانوى وفقاً للتعديل الذى تم في السلم التعليمي السوداني ليصبح ج- r-r ليتسق مع أغلب الدول الاسلامية . r ا ـ الاهتمام بالمكتبات والتقيف الذاتي في هذه المراحل الثلاث. با ـ العمل على توطين التعليم العالي داخل وادي النيل حفاظاً على هوبة الأمة وتوفير المعينات اللزمة له.

ء ا ـ مطلوبات الجامعة بجب أن تهنم بغرس الروح الوطنية وأخلاقيات المهنة ((خاصة في كليات الطب ،الهندسة)(في نفوس الطلاب وتعزبز العقبدة في النفوس ومحاربة الأفكار الهدامة كالثيوعية والوجودية مع التركيز على التربية الوطنية وقبول الاخر ..الخ.

1 ا ـإبراز التعدد العرقي والثقافي كقوة للدولة وليس عامل هدم لها. 17 ـ إصلاح التعليم الديني واخضاعه لسلطة الدولة لكى لا يفرز مخرجات سالبة كالتطرف والخرافات الثيعية. V ا ـ الاهتمام بالتعليم التقني والتقاني ل لدوره الفاعل في النهضة والتطور واستيعاب الرصبي التربوي.

1 1. الاهتمام بالنشاط الفكري والثقافي والرباضي للقضاء على العنف بالجامعاث.

9 1 ـ توظيف الفاقد التربوي(الرصد التربوي) في المجالات الفنيةوالحرفية وتبنى فتح معاهد له... •r. العمل على توفير معامل العلوم والحاسوب بالمدارس الثانوبة لتشجيع الطلاب لارتياد المثاق العلمي لأهميته فى تعزيز النهضة والتنمية . 


\section{الفزو الفكري والثقافي للامة الاسلامية التددي والاستجابة}

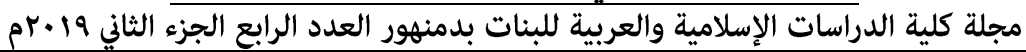

المطلب الثالث :- ضبط وسائل الثقافة (الإعلام - الأداب -القنون)

الاعلام:

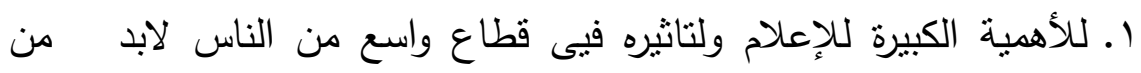

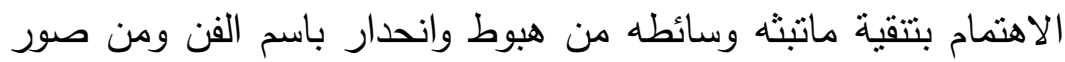

خليعة وعري وكلمات ساقطة ومفاهيم غربية تذخل للغرف المغلقة بغير

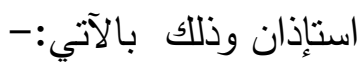

r. مراجعة مناهج كليات الاعلام وتحديثها وتأصيلها.

r. وضع السياسات الاعلامية التي تضبط القنوات والإذاعات والصحف

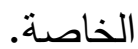

ع. التركيز على البرامج التي تستهدف البناء الثقافي والفكري للإنسان المسلم

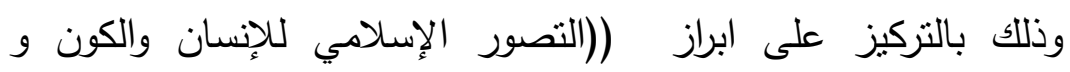

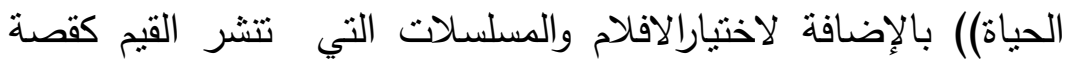

((بوسف وامرأة العزيز)) ((أبناء يعقوب عليه السلام)).... الخ وبثها في

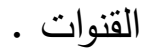

هـ أن تتولى الدولة تدريب الكوادر العاملة في وسائل الإعلام الخاصة. تفادياً

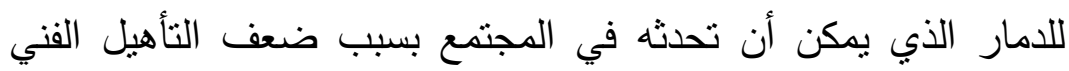

$$
\text { والأخلاقي. }
$$

T. العمل على الانتاج الداخلي للمسلسلات التى تعالج قضايا المجتمع كالجهل والمرض والعنصرية والجهوية وضعف الوطنية ونهب واستخلال ممنلكات

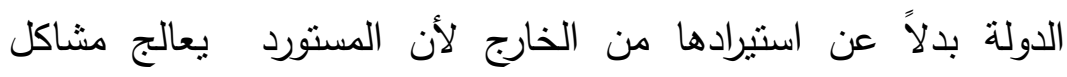

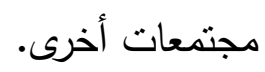

V. نشر ثقافة السلام والحوار واحترام الآخر وتوضيح حرمة الدماء والأموال وحب الوطن والتضحية من اجله. 1. تمهين الإعلام حتى لا يصبح مهنة من لا مهنة له له له 


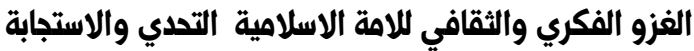

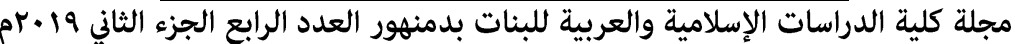

9 . أن تحدد أهداف واضحة للإعلام كأن يعمل على نشر ثقافة السلام و

الاهتمام بالزمن والعمل والإنتاج وحرمة الأموال العامة....الخ

• . مراقبه تتفيذ الإستراتيجية القومية للدولة في كل المحاور سياسية

\section{اقتصادية ، اجتماعية.}

ا ا التبشير بما يتم من إنجازات وإيجابيات في المجتمع والدولة لرفع الروح المعنوبة للمواطن وإنهاض الهمح وتجنب الاخبار السالبة التي تحبط الناس كالإعلان عن((فنثل موسم الإمطار مثثلً لها له من الاثر الاقتصادي والاجتماعي على الناس)) ((إلقاء القبض على قساوسة بتهمه التجسس ولما يترتب عليه من إثارة الغرب عموماً على بلادنا.)) وكموضوع ردة مريم وما ترتب عليه ،من إثارة موضوع عدم وجود الحريات الدينية في السودان والتي أصبحت واحدة من التهم التى تعمل الدولة الآن جاهدة لنفيها فى حوارها مع الغرب عموماً وأمريكا خاصة مها يكلف البلاد كثيرا من العناء كانت فى مندوحة عنه .

الأدب والفنون:

باسمهما وتحت غطاء الحرية الثخصية يعمل الغرب على نشر الفساد والاباحية والثذوذفي دول العالم الاسلامي لتوهين عرى الدين في النفوس ويضفي على رموز هذا الفساد من الالقاب ويمنحهم من الاموال والاوسمة والجوائز ما يخري الآخرين بالانخراط في هذه المفاسد باسم الفن للأثر الثقافي الهام لهذا المحور لابد من الآتي-: ا ـ الوقوف على مناهج وأساتذة الأدب والدراما في الكليات والتأكد من تأهيلهم

$$
\text { الفني والأخلاقي. }
$$

r. الفن والأدب من الوسائل التي تستخدم عادة لحمل الرسائل الفكرية والثقافية لكل أمة أو حزب او فكره او فلسفه فينبغي الاهتمام بالثعراء والأدباء والفنانين وتوظيف أدبهم لخدمة القضايا الوطنية والفكرية للمشروع الحضاري وذلك بطربقة مباشرة او غير مباشرة فشعراء وفنانين أمثال 


\section{الفزو الفكري والثقافي للاهة الاسلامية التددي والاستجابة}

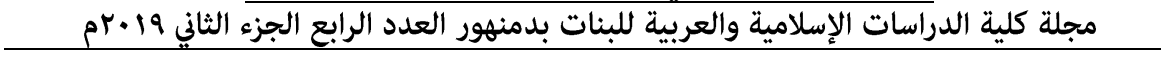

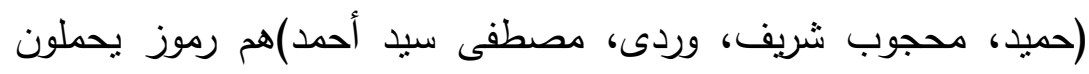

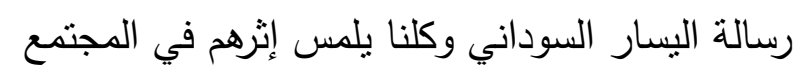

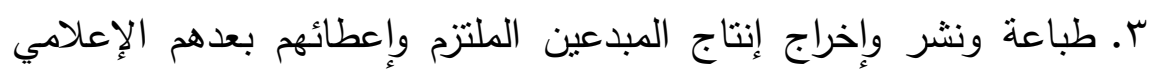

$$
\text { والأدبي يشجع الآخرين على الإنتاج. }
$$

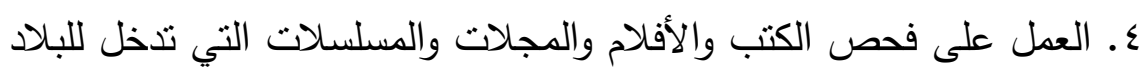

والتأكد من سلامتها الفكرية والثقافية والتتبه لأهدافها ومراميها.

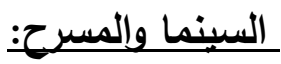

هما من أهم الأدوات والوسائل الثقافية ذات الأثز الكبير والواسع لذا

$$
\text { لابد من الآتي في التعامل معهما:- }
$$

ا ـ تشجيع الإنتاج الوطني المسرحي و السينمائي ليحل محل الأجنبي.

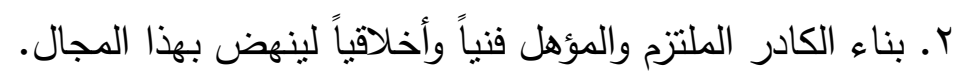

r. توجيه الإنتاج المسرحي والسينمائي لقضايا الأمة الفكرية والاجتماعية

والثقافية والسياسية كمحاربة النهب المسلح وحرمه الدماء وحرمة المال العام والعنصرية والجهوية والنطرف الديني والأفكار الهادمة كالعلمانية والثيوعية...الخ وتعزيز مفاهيم أخوة الفكرة والوطن وتقبل الآخر ..الخ. 


\section{الفزو الفكري والثقافي للاهة الاسلامية التداي والاستجابة}

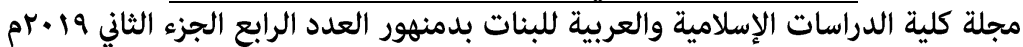

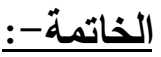

رغم ما يذل الغرب من جهود عسكرية وحربية وغزو فكري وثقافي

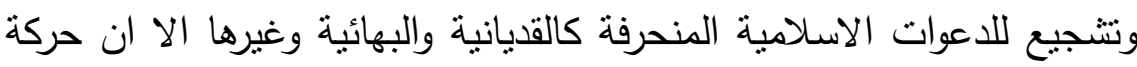

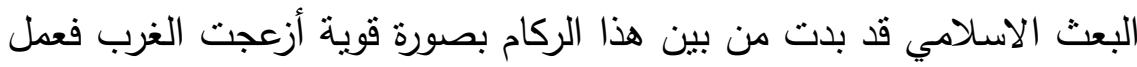

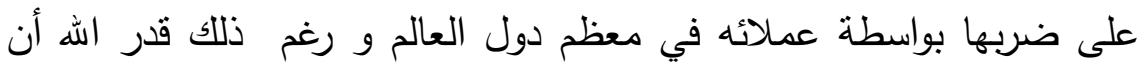

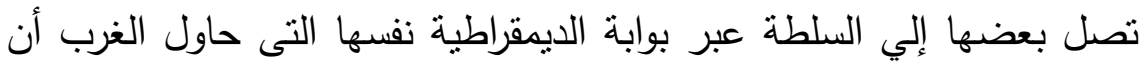
يغرضها نظاماً للحكم في العالم وفي كل الدول الاسلامية التى إجريت فيها

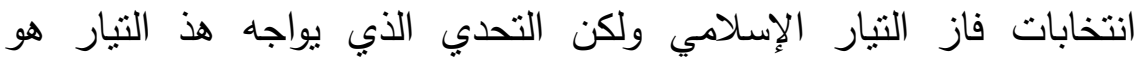
العمل.على تأصيل المعارف و العلوم وكل أوجه الحياة السياسية والاقتصادية والاجتماعية والاهتمام بتوضيح المفهوم الصحيح لاسلام بعتباره عقيدة

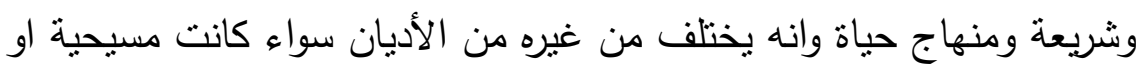

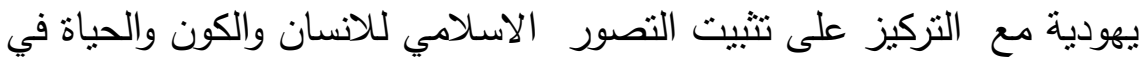
مناهج التعليم ووسائل الاعلام باعتبار أنها أهم وسائل نقل العلمانية لدول

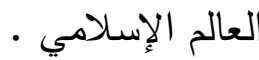




\section{المراجع}

1- عبد الباقي محد فؤاد - المعجم المفهرست لألفاظ القران الكريم/الدار

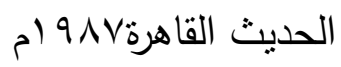

r- (- باموس الانجليزي ب- بائرة المعارف البربطانية ع - ابن منظور - لسان العرب المحيط دار الجيل بيروت 1988 ه - ابن حزم الظاهري أبو محمد أحمد - الفصل في الملل والأهواء والنحل

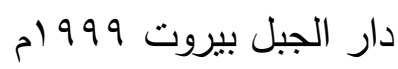

צ- ابن حزم الظاهري أبو محمد أحمد-الاحكام في اصول الاحكام دار الجيل

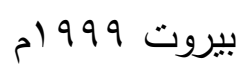

V- الصالح الثيخ صبحي - مباحث في علوم القران دار الفكر

$$
\text { بيروت } 910 \text { (الماتح }
$$

ᄉ- الصالح الثيخ صبحي - مباحث في علوم الحديث دار الفكر

$$
\text { بيروت } 910
$$

9- قطب محمد - مذاهب فكرية معاصرة دار الثروق القاهرة 1999

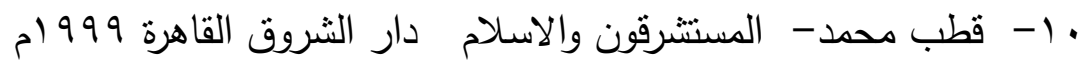
11- قطب محمد - النطور والثبات في حياة البشرية دار الثروق القاهرة

$$
\text { م) } 999
$$

r ا - قطب محمد- الانسان بين المادية والاسلام دار الثروق القاهرة 999 ام

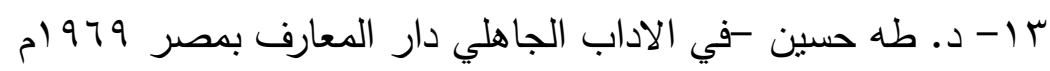

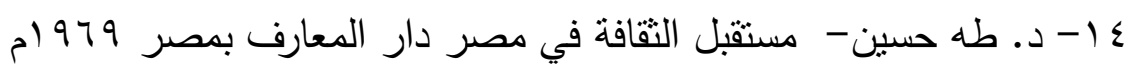

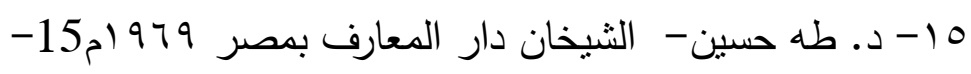

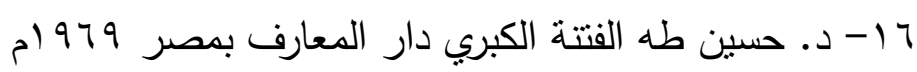

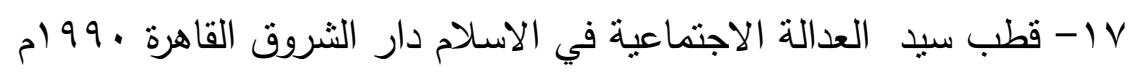




\section{الفزو الفكري والثقافي للاهة الاسلامية التداي والاستجابة}

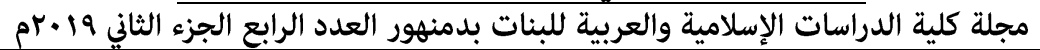

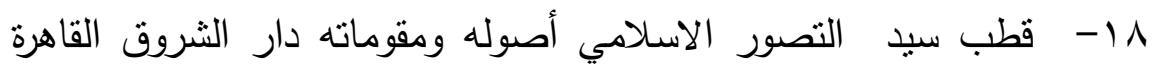

$$
\text { م) } 99 .
$$

19- مكي حسن التبشير في العاصمة القومية دار المركز الاسلامي

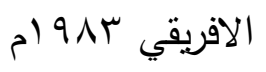

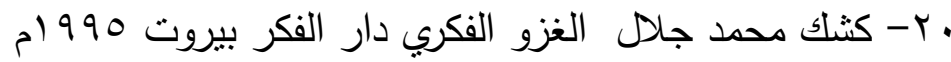

اY- كثلك محمد جلال القومية والغزو الفكري دار الفكر بيروت 990 ام

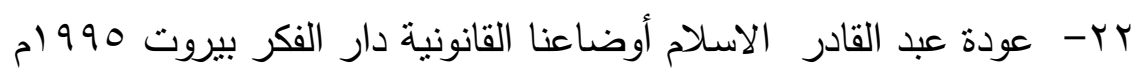

r آ- عودة عبد القادر النتربع الجنائي الاسلامي دار الفكر بيروت 1990

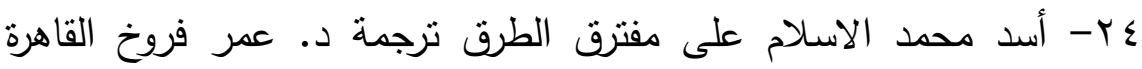

$$
\text { 5) }
$$

هץ- شاتلييه - الغارة على العالم الاسلامي ترجمة محي الدين الخطيب القاهرة

$$
\text { م) } 199 \text {. }
$$

צr- إقبال محمد- تجديد الفكر الديني ترجمة عباس محمود العقاد القاهرة

$$
\text { م) } 970
$$

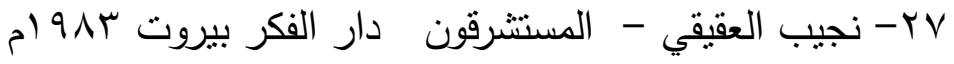

$$
\begin{aligned}
& \text { ب - لورد كرومر مصر الحديثة القاهرة } 90 \text { ام. }
\end{aligned}
$$

